\title{
Visual Evaluation of Regional Tourism Attractiveness Based On Transportation: a GIS Quantitative Analysis Method
}

Xiaochun Qin ( $\nabla$ xcqin@bjtu.edu.cn )

Beijing Jiaotong University

Fantong Meng

Beijing Jiaotong University

Michael Meitner

University of British Columbia

Anchen Ni

Beijing Jiaotong University

\section{Research Article}

Keywords: Analytic Hierarchy Process(AHP), Geographic Information System(GIS), Quantitative and Visual Evaluation, Tourism Attractiveness, Tourism Transportation

Posted Date: September 22nd, 2021

DOl: https://doi.org/10.21203/rs.3.rs-850252/v1

License: (9) (1) This work is licensed under a Creative Commons Attribution 4.0 International License. Read Full License 


\section{Abstract}

The research in evaluating regional transportation tourism attractiveness has mainly based on qualitative or semi-quantitative analysis, and it has not been achieved quantitative and visual evaluation. The quantitative evaluation method of regional tourism attractiveness was established by employing the analytic hierarchy process and Delphi method in this paper. Moreover, the evaluation of tourism attractiveness was divided into four factors: natural condition index, tourism condition index, transportation condition index, and social economy index. The index weight was obtained by the judgment matrixes, and the weighted overlay analysis method using ArcGIS was adapted to study the coordinated development of tourism transportation. The results show that it was scientific and feasible to make a quantitative and visual tourism attractiveness evaluation based on the four aspects of natural condition, tourism condition, transportation condition, and social economy through the verification of a case study of the Great Jiuzhai Ring Tourist Area. The research revealed that the transportation system and the tourism system interacted with each other and had an excellent positive feedback mechanism, which could further promote the integrated development of transportation and tourism, and play theoretical and methodological guiding significance on regional tourism transportation network planning based on tourism resources.

\section{Introduction}

With the rapid development of regional tourism, people have more and more personalized demands for tourism, considering the natural and cultural heritage of scenic spots and the experience and comfort of the tourism process. The tourism attractiveness evaluation [1-3] comes into being, with the tourism industry having transformed from traditional sightseeing tours to experiential and personalized tourism. In previous studies, common methods for evaluating tourism attractiveness included aesthetic quality evaluation, the artificial neural network, and AHP. Aesthetic quality evaluation was susceptible to subjective factors. The Delphi method is efficient to assess professional academic and practitioner opinions from experts in the field because of its appropriateness for evaluating tourism attractiveness and its flexibility with small samples. Ristić applied SWOT analysis by the questionnaire to determine the tourism development in rural areas [4]. Trukhachev put forward a methodology based on the Delphi method to evaluate the rural tourism attractiveness to discover their specific advantages and disadvantages and then consider tourism policy and product development and promotion [5]. The artificial neural network had strong adaptability and strong learning ability but required specific learning samples [6]. Giglio used social media and machine learning models approach to identify tourism attractiveness [7]. It was helpful for the analytic hierarchy process (AHP) and F-AHP to understand decision-making factors and their relative weights, but there are also subjective preferences of experts. Zhou applied a hybrid analytic hierarchy process to evaluate West Virginia's resource-based tourism competitiveness, and proved that the AHP was a reliable tool to evaluate destination tourism attractiveness [2]. Zabihi firstly integrated Geographic Information System (GIS) with a Fuzzy-Analytic Hierarchy Process (F-AHP) to evaluate ecotourism suitability [8]. In contrast, AHP was more 
straightforward and more feasible to operate, ensuring that the evaluation content is reasonable and reliable and simplifies the complexity of the problem. The attractiveness of tourism resources was evaluated by selecting specific evaluation indicators, which affected the direction and scale of tourism resources' development to meet changing tourism needs. Countries around the world have developed classification standards for tourism resources. For example, the World Tourism Organization divides tourism resources into three categories and nine groups. China has also formulated national classification standards and principles of tourism resources for reference [9]. Correspondingly, the tourism resources' evaluation has become more detailed, and relevant research on rural tourism [5], ecotourism, and glacier tourism has gradually increased. Wang established a spatial assessment system based on AHP and thought about improving China's glacier tourism attractiveness [10].

More and more attention has been paid to tourism transportation in recent years, and a series of studies on their relationship, planning, and coordinated development have been launched [11-14]. Tang firstly reconfigured conventional tourism system models by identifying an innovative and potentially lucrative stopover-to-stayover tourism conversion function that strongly implicated the air transport industry [11]. Albalate assessed how high-speed rail affected tourism through the comparative analysis of China and Spain [12]. The relationship between international tourism, transportation, travel, and transport services has been evaluated in Rehman's study [14]. Considering transportation effects on tourism to promote the synergistic development of transportation and tourism, strengthening the integration of transportation system and tourism system, which is the inevitable trend of sustainable development [15] of transportation and tourism by strengthening aesthetic design of the tourist experience, especially for regional tourism. Existing research on tourism attractiveness has been mainly based on qualitative descriptive, statistical analysis, or semi-quantitative analysis [16-18] and mainly focused on related theories. While most of them were limited to the tourism evaluation of a specific place and lacked comprehensiveness analysis, little visualization of conclusions was made. The guiding role of tourism transportation planning was limited.

With the development and widespread application of big data, GIS is gradually used in tourism informatization research, tourism planning, and development [19-21], making it possible to quantify and visualize tourism transportation network planning. It became possible to combine mathematical modeling with GIS such as AHP [22-23], artificial neural networks [24-25], and other mathematical methods [26] to evaluate the tourism resources quantitatively, and then provided data support for tourism resource development and planning, and realized the sustainable development of regional tourism. Many scholars have established evaluation systems by AHP, Delphi method, and GIS and have examined the evaluation indexes $[8,27,28]$. Mishra proposed a methodology to identify suitable organic farming sites using AHP and GIS [22]. Yu established Ecotourism Relevancy Evaluation through the application of GIS and Artificial Neural Network Model [24]. González-Ramiro used publicly available data and volunteered geographic information platforms to assess the spatial distribution of rural tourism potential [26]. Cheng used the Delphi method and AHP to build an evaluation index system for low-carbon tourist attractions [27]. However, most of the GIS applications in tourism transportation mainly concentrated on transportation accessibility, and there was no further analysis of how transportation affected 
attractiveness. The development of roads and railways provided opportunities to attract tourists to their regions [29]. Transport infrastructure was positively related to community support for tourism [30].

Therefore, how to quantitatively evaluate and visualize each region's tourism attractiveness based on the distribution of tourism resources and other parameters is a problem worthy of study. This research aims to establish a quantitative and visual evaluation method of tourism attractiveness by integrating AHP, Delphi method, and GIS, and then obtain the relationship between the transportation system and the tourism system to provide helpful guidance for regional tourism resources planning. The quantitative evaluation system of tourism attractiveness was proposed using the AHP and the Delphi method first. Then the index's weight was obtained by solving the judgment matrixes established through the expert scoring method. The ArcGIS spatial analysis was used to realize the visualization and quantification of tourism attractiveness. Finally, Research on the regional impact of tourism resources attractiveness provides valuable insights for policy-makers, planners, and practitioners. We want to achieve a methodological attempt to provide new insights into tourism attractiveness evaluation.

\section{Method}

\section{A. Establishment Of Quantitative Evaluation System of Tourism Tttractiveness By AHP And Delphi Method}

The regional tourism attractiveness evaluation is a comprehensive analysis and evaluation system with multiple indicators. Since each evaluation indicator has a different degree of influence on tourism attractiveness, different weights can be assigned according to its importance. So, this evaluation system is obtained by AHP and Delphi method. First, the evaluation index is studied $[8,27,28]$, and then the questionnaire is issued to obtain the relative importance score, and the evaluation index is revised, and the final evaluation system is obtained by repeating three times.

A total of 50 questionnaires were issued in this survey. The study was approved by Beijing Jiaotong University. The evaluation questionnaires were performed in accordance with relevant regulations of Beijing Jiaotong University, and the participants signed an informed consent form prior to research commencement. The informed consent was obtained from all the subjects involved in the questionnaires. 35 valid questionnaires were collected, including 24 experts and scholars engaged in tourism attractiveness research, tourism geography, and economics in universities and scientific research institutions, four decision-makers from government agencies, seven managers, or operators from tourism departments.

Details of each processing step are shown in Fig. 1.

1) Index Selection of The Quantitative Evaluation System of Regional Tourism Attractiveness: Based on the results of two rounds of index selection and the analysis of these findings, tourism attractiveness is divided into four factors and then further subdivided into nine indices, as shown in Table I. The natural 
condition index reflects the tourist area's topography, and the plains can give tourists more comfortable feelings. The tourism condition index is the core factor of tourism attractiveness, reflecting the abundance of tourism resources and the degree of attractiveness to tourists. The transportation condition index is an essential factor of tourism attractiveness, representing the accessibility of scenic spots. The social economy index represents the economic and tourism development level in the region and reflects tourists' comfort and satisfaction.

The Criterion level reflects the main influencing factors of tourism attractiveness, and the Index level is the specific index used to characterize the Criterion level. Altitude classification was based on the internationally accepted altitude classification standard combined with the critical altitude of altitude sickness $(2400 \mathrm{~m})$. Studies have shown that when people travel on mountain plateaus, the hypoxic environment exerts a significant negative impact on human cognitive ability and physiological well-being $[31,32]$. Slope classification was based on the relevant national standard [33]. Tourism resources attraction reflects the degree of attractiveness of scenic spots to tourists. Due to the different grades of scenic spots, the degree of attractiveness to tourists is also different, so different weights are assigned to them, and then kernel density analysis of point element is used to calculate tourism resources attractiveness. Tourism resource aggregation represents the number of scenic spots in a specific region regardless of each scenic spot's weight value and is calculated by kernel density analysis of the point element. Transportation hub density is the density of the distribution of the transportation hubs. Due to the different levels of the hubs, the radiation radii are also different, so different weights are assigned to them, and then kernel density analysis of point element is used to calculate transportation hub density. Transportation accessibility represents the traffic convenience of scenic spots in the area. Airports, railways, highways, national highways, and provincial highways are assigned different radiation radii, and a multi-ring buffer analysis is used to obtain the degree of impact of the transportation system on the entire region. The weighted layer of tourism transportation accessibility in the region is carried out according to the proportion of different transportation modes. Economic development level takes the regional Gross Domestic Product (GDP) as the evaluation indicator by unscrambling Reports on the Work of the Government. The tertiary industry's development level takes the regional GDP of the tertiary industry as the evaluation indicator by unscrambling Reports on the Work of the Government. Industry support in the region is usually indicated by the proportion of the tertiary industry in GDP.

\section{TABLE I THE EVALUATION SYSTEM OF REGIONAL TOURISM ATTRACTIVENESS}




\begin{tabular}{|c|c|c|}
\hline Target layer & Criterion layer & Index layer \\
\hline \multirow{10}{*}{$\begin{array}{l}\text { the Evaluation System of Regional } \\
\text { Tourism Attractiveness }\end{array}$} & \multirow{2}{*}{$\begin{array}{l}\text { Natural condition index } \\
\text { (1) }\end{array}$} & Altitude(1.1) \\
\hline & & Slope(1.2) \\
\hline & \multirow{2}{*}{$\begin{array}{l}\text { Tourism condition index } \\
\text { (2) }\end{array}$} & $\begin{array}{l}\text { Tourism Resources } \\
\text { Attraction(2.1) }\end{array}$ \\
\hline & & $\begin{array}{l}\text { Tourism Resources } \\
\text { Aggregation(2.2) }\end{array}$ \\
\hline & \multirow[t]{2}{*}{$\begin{array}{l}\text { Transportation condition } \\
\text { index (3) }\end{array}$} & $\begin{array}{l}\text { Transportation Hub } \\
\text { Density(3.1) }\end{array}$ \\
\hline & & $\begin{array}{l}\text { Transportation } \\
\text { Accessibility(3.2) }\end{array}$ \\
\hline & \multirow{4}{*}{$\begin{array}{l}\text { Social economy index } \\
\text { (4) }\end{array}$} & $\begin{array}{l}\text { Economic Development } \\
\text { Level(4.1) }\end{array}$ \\
\hline & & The Development Level of \\
\hline & & Tertiary Industry(4.2) \\
\hline & & Industry Support(4.3) \\
\hline
\end{tabular}

2) Determination of the Evaluation Index Weights: The specific determination of the evaluation indices' weighs was as follows:

a) Establish judgment matrixes: The scale value filled in the judgment matrix " $\mathrm{A}$ " was given from 1-9 or its reciprocal by comparing the row index with the column index.

The weight of each index was determined using the AHP and the third round of questionnaires, 35 experts were invited to score the various indexes of the evaluation system, and comparison judgment matrixes of evaluation indices at various levels were established:
$A=\left[\begin{array}{cccc}1 & 1 / 5 & 1 / 3 & 1 / 2 \\ 5 & 1 & 2 & 3 \\ 3 & 1 / 2 & 1 & 2 \\ 2 & 1 / 3 & 1 / 2 & 1\end{array}\right] \quad A_{1}=\left[\begin{array}{ll}1 & 1 \\ 1 & 1\end{array}\right] \quad A_{2}=\left[\begin{array}{cc}1 & 5 \\ 1 / 5 & 1\end{array}\right]$
$A_{3}=\left[\begin{array}{cc}1 & 1 / 4 \\ 4 & 1\end{array}\right] \quad A_{4}=\left[\begin{array}{ccc}1 & 2 & 2 \\ 1 / 2 & 1 & 1 \\ 1 / 2 & 1 & 1\end{array}\right]$

b) Solve the judgment matrixes: The following Eq. (1) could be used to calculate the root of all elements in each row of the judgment matrixes, 
$\bar{w}_{i}=\sqrt[n]{\prod_{j=1}^{n} a_{i j}}$

The normalized values could be normalized respectively according to Eq. (2).

$w_{j}=\frac{\bar{w}_{i}}{\sum_{j=1}^{n} \bar{w}_{j}}$

The weight value of each indicator and the normalized weight value were shown in Table II.

TABLE II THE WEIGHT VALUE OF EACH INDICATOR AND THE NORMALIZED WEIGHT VALUE

\begin{tabular}{|c|c|c|}
\hline indexes & The weight value & the normalized weight value \\
\hline A $\bar{W}$ & $=(0.088,0.483 \bowtie 0.272 \bowtie 0.157)^{\top}$ & $W=(0.09,0.483 \otimes 0.272 \varangle 0.157)^{\top}$ \\
\hline A1 $\bar{W}$ & $=(1,1)^{\top}$ & $W=(0.5,0.5)^{\top}$ \\
\hline A2 $\bar{W}$ & $=(2.236,0.4472)^{\top}$ & $W=(0.83,0.17)^{\top}$ \\
\hline A3 $\bar{W}$ & $=(0.5,2)^{\top}$ & $W=(0.2,0.8)^{\top}$ \\
\hline A4 $\bar{W}$ & $=(1.5874,0.7937 \rrbracket 0.7937)^{\top}$ & $W=(0.5,0.25 \bowtie 0.25)^{\top}$ \\
\hline
\end{tabular}

c) Assessing matrix consistency. A general consistency of all judgments is required, and the index weight will not be reliable as a basis for decision making if the judgments are too inconsistent. To check the consistency of the matrix, the following indexes are calculated:

$C I=\frac{\lambda_{\max }-n}{n-1}$

$C R=\frac{C I}{R I}$

(4)

where $\mathrm{Cl}$ is the consistency index, $\lambda_{\max }$ is the maximum characteristic root of the judgment matrix, and RI is the average random consistency index (Table III). CR is the random consistency proportion. When CR equals 0 , the judgment matrix has a perfect consistency, and the CR value increases as the judgment matrix become more inconsistent. The judgment matrix has an acceptable consistency when $\mathrm{CR}<0.1$.

TABLE III TTE NUMERICAL VALUE OF RI [34, 35]

\begin{tabular}{|llllllllll|}
\hline $\mathbf{N}$ & $\mathbf{2}$ & $\mathbf{3}$ & $\mathbf{4}$ & $\mathbf{5}$ & $\mathbf{6}$ & $\mathbf{7}$ & $\mathbf{8}$ & $\mathbf{9}$ & $\mathbf{1 0}$ \\
$\mathrm{RI}$ & 0 & 0.58 & 0.89 & 1.12 & 1.24 & 1.32 & 1.41 & 1.45 & 1.49 \\
\hline
\end{tabular}


The consistency test was performed to ensure that the CR values of both the single-level ranking and the total level ranking were less than 0.01 , and the evaluation system was obtained as shown in Table IV below.

TABLE IV QUANTITATIVE EVALUATION INDEX OF REGIONAL TOURISM ATTRACTIVENESS

\begin{tabular}{|c|c|c|c|c|}
\hline Target layer & Criterion layer & weight & Index layer & weight \\
\hline \multirow[t]{9}{*}{$\begin{array}{l}\text { the Evaluation System of } \\
\text { Regional Tourism Attractiveness }\end{array}$} & $\begin{array}{l}\text { Natural condition } \\
\text { index }\end{array}$ & 0.09 & Altitude(1.1) & 0.5 \\
\hline & $(1)$ & & Slope(1.2) & 0.5 \\
\hline & $\begin{array}{l}\text { Tourism } \\
\text { condition index }\end{array}$ & 0.48 & $\begin{array}{l}\text { Tourism Resources } \\
\text { Attraction(2.1) }\end{array}$ & 0.83 \\
\hline & (2) & & $\begin{array}{l}\text { Tourism Resources } \\
\text { Aggregation(2.2) }\end{array}$ & 0.17 \\
\hline & $\begin{array}{l}\text { Transportation } \\
\text { condition index }\end{array}$ & 0.27 & $\begin{array}{l}\text { Transportation Hub } \\
\text { Density(3.1) }\end{array}$ & 0.2 \\
\hline & (3) & & $\begin{array}{l}\text { Transportation } \\
\text { Accessibility(3.2) }\end{array}$ & 0.8 \\
\hline & $\begin{array}{l}\text { Social economy } \\
\text { index }\end{array}$ & 0.16 & $\begin{array}{l}\text { Economic Development } \\
\text { Level(4.1) }\end{array}$ & 0.5 \\
\hline & (4) & & $\begin{array}{l}\text { The development Level } \\
\text { of Tertiary Industry(4.2) }\end{array}$ & 0.25 \\
\hline & & & Industry Support(4.3) & 0.25 \\
\hline
\end{tabular}

\section{B. Visual Analysis Of Tourism Attractiveness Based On GIS Spatial Analysis}

The quantitative and visual evaluation results of regional tourism resources attractiveness were realized by ArcGIS's spatial analyst. The spatial analysis methods involved in this research mainly included:

1) Buffer Analysis: In the study of the regional tourism resources attractiveness, based on the existing traffic system data, buffer analysis of transportation accessibility was made to precisely determine their impact areas and impact levels. Buffer analysis was also employed to plan tourist routes [36] and analyze the relationship between urban green space and population distribution to improve mapping accuracy [37].

2) Digital Terrain Analysis: Based on the project area's remote sensing data, the surface analysis toolset was used to select representative terrain index as the evaluation system indicators. Topography is an essential factor in the evaluation of tourism resources $[8,38]$. 
3) Kernel Density Analysis: Different levels of scenic spots and transportation hubs were given different weights to analyze the distribution of regional tourism resources and the density of transportation hubs, and then analyze their tourism attractiveness.

4) Overlay Analysis: Each evaluation indicator was uniformly graded, and then a weighted overlay was used to combine them $[8,39]$.

\section{Results And Discussion}

\section{A. Study Case}

The Great Jiuzhai Ring Tourist Area, one of the most popular tourist areas in China, has rich tourism resources, but the transportation system is unbalanced because of the undulating terrain. The analysis of tourism attractiveness is representative and essential, and the relevant data in this area is comprehensive. The quantitative and visual tourism attractiveness evaluation was realized by the weighted overlay analysis method to study the coordinated development of tourism transportation in the region, which could play theoretical and methodological guiding significance on regional tourism transportation network planning.

1) Distribution of Traffic and Tourism: The Great Jiuzhai Ring Tourist Area is located in the northern plateau of Sichuan Province, northeast of Tibetan Qiang Autonomous Prefecture of Ngawa, covering 32,000 square kilometers, more than 300 kilometers away from Chengdu. The tourism industry in this region is well developed with a comprehensive and reasonable transportation system. The railway networks, highway networks, national highway networks, provincial highway networks, and five airports have been established.

The WGS_1984_UTM_Zone_48N coordinate system was selected for spatial analysis in ArcGIS, then the distribution vectors of scenic spots and transportation system were obtained by georeferencing the corresponding distribution maps of regional scenic spots and transportation system. The corresponding distribution maps were shown in Fig. 2(a), and the corresponding vectors were shown in Fig. 2(b).

2) GIS Data and Social Economy Data: This article's GIS vector data includes administrative boundaries and elevation and comes from the National Basic Geographic Information Center in 2018. DEM data comes from the geospatial data cloud SRTMDEMUTM digital elevation data product, with a spatial resolution of $90 \mathrm{~m}$; social economy data such as regional GDP and the development level of the tertiary industry are derived from the 2019 government work reports of the counties and districts of the Great Jiuzhai Ring Tourist Area (shown in Table V).

TABLE V ECONOMIC AND INDUSTRIAL LEVEL OF THE GREAT JIUZHAI RING TOURIST AREA 


\begin{tabular}{|c|c|c|c|c|c|c|c|}
\hline cities & GDP & $\begin{array}{l}\text { tertiary } \\
\text { industry }\end{array}$ & $\begin{array}{l}\text { Industry } \\
\text { support }\end{array}$ & cities & GDP & $\begin{array}{l}\text { tertiary } \\
\text { industry }\end{array}$ & $\begin{array}{l}\text { Industry } \\
\text { support }\end{array}$ \\
\hline $\begin{array}{l}\text { Jiuzhaigou } \\
\text { Village }\end{array}$ & 22.34 & 16.45 & $73.66 \%$ & An Village & 72.65 & 28.45 & $39.16 \%$ \\
\hline $\begin{array}{l}\text { Hongyuan } \\
\text { Village }\end{array}$ & 9.25 & 5.57 & $60.20 \%$ & $\begin{array}{l}\text { Mianyang } \\
\text { core area }\end{array}$ & 781.88 & 383.90 & $49.10 \%$ \\
\hline $\begin{array}{l}\text { Songpan } \\
\text { Village }\end{array}$ & 13.53 & 7.86 & $58.10 \%$ & $\begin{array}{l}\text { Wenchuan } \\
\text { Village }\end{array}$ & 36.46 & 21.83 & $59.87 \%$ \\
\hline $\begin{array}{l}\text { Pingwu } \\
\text { Village }\end{array}$ & 26.59 & 13.05 & $49.10 \%$ & $\begin{array}{l}\text { Mianzhu } \\
\text { City }\end{array}$ & 110.13 & 41.57 & $37.75 \%$ \\
\hline $\begin{array}{l}\text { Qingchuan } \\
\text { Village }\end{array}$ & 24.08 & 12.00 & $49.84 \%$ & Shifang City & 129.28 & 51.63 & $39.93 \%$ \\
\hline $\begin{array}{l}\text { Chaotian } \\
\text { District }\end{array}$ & 27.23 & 11.54 & $42.38 \%$ & $\begin{array}{l}\text { Pengzhou } \\
\text { City }\end{array}$ & 179.39 & 61.24 & $34.14 \%$ \\
\hline $\begin{array}{l}\text { Lizhou } \\
\text { District }\end{array}$ & 138.08 & 58.52 & $42.38 \%$ & Deyang City & 476.87 & 198.21 & $41.57 \%$ \\
\hline $\begin{array}{l}\text { Zhaohua } \\
\text { District }\end{array}$ & 27.65 & 11.72 & $42.38 \%$ & Dujiangyan & 278.48 & 182.68 & $65.60 \%$ \\
\hline $\begin{array}{l}\text { Jiangyou } \\
\text { City }\end{array}$ & 210.71 & 97.30 & $46.18 \%$ & $\begin{array}{l}\text { Guanghan } \\
\text { City }\end{array}$ & 183.14 & 74.36 & $40.60 \%$ \\
\hline $\begin{array}{l}\text { Jiange } \\
\text { Village }\end{array}$ & 46.10 & 14.85 & $32.20 \%$ & $\begin{array}{l}\text { Xindu } \\
\text { Village }\end{array}$ & 521.10 & 329.23 & $63.18 \%$ \\
\hline Mao Village & 18.98 & 11.02 & $58.10 \%$ & Pidu District & 414.36 & 271.71 & $65.57 \%$ \\
\hline $\begin{array}{l}\text { Beichuan } \\
\text { Village }\end{array}$ & 42.31 & 24.23 & $57.27 \%$ & $\begin{array}{l}\text { Qingbaijiang } \\
\text { District }\end{array}$ & 345.52 & 227.01 & $65.70 \%$ \\
\hline $\begin{array}{l}\text { Zitong } \\
\text { Village }\end{array}$ & 63.33 & 28.99 & $45.78 \%$ & $\begin{array}{l}\text { Chengdu } \\
\text { core area }\end{array}$ & 3906.54 & 2561.67 & $65.57 \%$ \\
\hline $\begin{array}{l}\text { Longquanyi } \\
\text { District }\end{array}$ & 466.70 & 165.15 & $35.39 \%$ & & & & \\
\hline
\end{tabular}

\section{B. Visual And Quantitative Analysis Of Evaluation Indicators}

1) Altitude Analysis: The altitude information was extracted from the DEM data of the Great Jiuzhai Ring Tourist Area, and the altitude classification layer of the Great Jiuzhai Ring Tourist Area was obtained as shown in Fig. 3 below.

2) Slope Analysis: According to the slope vector of the Great Jiuzhai Ring Tourist Area, the extracted slopes were graded and classified. The slope classification layer of the Great Jiuzhai Ring Tourist Area was shown in Fig. 4 below. 
The Sichuan Basin has small slopes, relatively flat terrain, and low altitude.

3) Tourism Resources Attraction: The Great Jiuzhai Ring Tourist Area includes five 5A-grade scenic spots (Qingcheng Mountain-Dujiangyan Scenic Area, Wenchuan Special Tourist Area, Huanglong, Jiuzhaigou, Beichuan Qiangcheng Tourist Area), thirty 4A-grade scenic spots (Sanxingdui ruins, Yaowang Valley, Jianmen Pass, etc.). The nuclear density of scenic spots is often a concentric circle, and the level of scenic spots is different; the range of influence and the intensity of attenuation are also different, and different weights are assigned to it. The weights of the world-class attractions, national attractions, 5Agrade scenic spots, 4A-grade scenic spots, and other attractions are 6,4,5,4,3. The vector of tourism resources attraction in the Great Jiuzhai Ring Tourist Area could be obtained by utilizing kernel density analysis in ArcGIS and divided by the natural breakpoint classification method into five grades to generate new raster data, as shown in Fig. 5 below.

The primary tourism resources of the Great Jiuzhai Ring Tourist Area are mainly concentrated in the Qingcheng Mountain-Dujiangyan Scenic Area, Huanglong-Jiuzhaigou Valley, and Guangyuan City. Overall, the scenic spots in the Great Jiuzhai Ring Tourist Area present a typical aggregation effect. Due to the abundant tourist resources and flat terrain, the southern plain area has formed an attractive tourism cluster. Moreover, Jiuzhaigou in the north also attracts many tourists.

4) Tourism Resources Aggregation: The raster data of tourism resources aggregation was calculated and processed using nuclear density analysis tools and then could be divided by the Jenks natural breaks classification method into five grades to generate new raster data, as shown in Fig. 6 below.

In general, the tourist scenic spots of the Great Jiuzhai Ring tourist area are relatively concentrated. The scenic spots in the southeast Chengdu area are the most concentrated, and the tourism resources are the most abundant, which is also a well-known tourist district in China. The rest of the scenic spots also show a specific cluster effect, distributed in several major tourist cities.

5) Transportation Hub Density: The Great Jiuzhai Ring Tourist Area has three first-level transportation hubs, ten second-level hubs, and four third-level hubs to help tourists quickly gather and distribute. The density vector of the major transportation hubs in the Great Jiuzhai Ring tourist area could be obtained by utilizing kernel density analysis in ArcGIS and then divided by the Jenks natural break classification method into five levels to generate new raster data, as shown in Fig. 7 below.

The southern area has a developed economy and a large population, so there are many transportation hubs. The Jiuzhaigou-Huanglong Scenic Area in the north is also a hotspot of transportation hubs convenient for tourists.

6) Transportation Accessibility: The Great Jiuzhai Ring Tourist Area is dominated by land transportation. This study's transportation data mainly include airports, railways, highways, national highways, and provincial highways. The obtained data was rasterized with a resolution of $30 \mathrm{~m}$. In this paper, the radiation radius of the airport, railway, highways, national highways, and provincial highways were $50 \mathrm{~km}$, 
$40 \mathrm{~km}, 30 \mathrm{~km}, 20 \mathrm{~km}, 10 \mathrm{~km}$, and their accessibilities were attenuated by $10 \mathrm{~km}$. Airports, railways, and highways with fast speed and short time service tourists from all over the world, so the radiation radius is larger; while national highways and provincial highways with slow speed and longtime serve more local tourists, so the radiation radius is small. The accessibility of each transportation was obtained in Fig. 8.

The proportion of different transportation was estimated in tourism travel combined with the actual traffic conditions in the tourist area. It was estimated that the proportion of airplane travel, railway travel, highway travel, national highway travel, provincial highway travel in tourism travel was $14.73 \%, 32.41 \%$, $19.25 \%, 23.94 \%, 9.67 \%$ [40]. The transportation accessibility of the Great Jiuzhai Ring Tourist Area was obtained by the weighted overlay, then rasterized with a resolution of $30 \mathrm{~m}$, as shown in Fig. 9.

According to the classification layer of transportation accessibility, it can be seen that the tourism area of The Great Jiuzhai Ring Tourist Area has good transportation accessibility in the southeast plain area, inconvenient transportation in the northwest mountainous area, and convenient transportation and good connectivity in the southeast zone. There is Jiuzhai Huanglong Airport in Songpan Village with the right traffic conditions close to Huanglong and Jiuzhaigou scenic spots.

7) Economic Development Level: Economic development level was divided by Jenks natural breaks classification method into five levels, then resampled into raster data with a resolution of $30 \mathrm{~m}$, as shown in Fig. 10.

The economic development level of the Great Jiuzhai Ring Tourist Area has shown a developed southeast and a weak northwest, which is because Chengdu, as the capital of Sichuan Province and a new first-tier city, has a high level of economic development, radiating into the surrounding plains and driving the development of surrounding counties and cities. However, the northwestern part is relatively lagging due to high terrain, significant topographic changes, and inconvenient transportation.

8) the Development Level of Tertiary Industry: The development level of the tertiary industry was divided by Jenks natural breaks classification method into five levels, then resampled into raster data with a resolution of 30m, as shown in Fig. 11.

Tourism is an essential part of the tertiary industry. The more people engaged in the tertiary industry in a region, the more developed the service industry in the region, and the more tremendous potentiality for regional tourism development and job creation. As far as this region was concerned, there were developed economic and rich tourism resources with great attractiveness in the southeast, so the tertiary industry was advanced. The relatively slow development of the northeast and northwest was closely related to the low level of economic development.

9) Industry Support: Industry support was divided by equal interval classification method into five levels, as shown in Fig. 12 below.

Based on the collected statistics of the tertiary industry in the Great Jiuzhai Ring Tourist Area in 2019, it can be seen that the tertiary industry in this area has a relatively high proportion, and the proportion of 
tertiary industry in all counties is above $30 \%$, which matches the region's abundant high-quality tourism resources while the primary industry is weak and the service industry is relatively developed. The proportion of tertiary industry in various districts and counties is also very different; the highest in Jiuzhaigou Village has reached $73.66 \%$, while the lowest in Jiange Village has only $32.20 \%$. The reason for the big difference from Fig. 10 was that Chengdu, Dujiangyan had rich tourism resources, convenient transportation, and developed economy, which were highly suitable for the development of tourism resources, so the tertiary industry accounted for a relatively high proportion of regional GDP; In contrast, the economic development level of Jiuzhaigou and Songpan counties was relatively low, but tourism resources were relatively abundant, so the tertiary industry had an undeniable boost to their economy. C. Comprehensive Evaluation Of Tourism Attractiveness

To create a comprehensive evaluation of tourism attractiveness, we multiplied each index classification layer by the corresponding expert derived weights to obtain the four major criterion layer index classifications. The calculation results were divided into five levels according to the data interval $0 \sim 1,1$ $\sim 2,2 \sim 3,3 \sim 4,4 \sim 5$, represented by numbers 1 to 5 respectively, and resampled into raster data with a resolution of $30 \mathrm{~m}$.

1) Natural Condition Index: The natural condition index included two specific index factors of altitude and slope, and the result was shown in Fig. 13 below.

2) Tourism Condition Index: The tourism condition index included two specific indicators of tourism resources aggregation and tourism resources attraction, and the result was shown in Fig. 14 below.

The distribution of tourism condition index in the Great Jiuzhai Ring tourist area was not equally distributed, and the tourism conditions in the entire area were ordinary. The distribution of tourism resources was very concentrated, with Chengdu being the most concentrated area and JiuzhaigouHuanglong Scenic Area, Guangyuan City being the second-level concentrated area, which was very conducive to the development and utilization of tourism resources, forming a regional characteristic tourism center.

3) Transportation Condition Index: A weighted overlay was performed to combine the transportation hub density with transportation accessibility to evaluate the regional transportation system, and the result is shown in Fig. 15 below.

There was good transportation accessibility with dense networks and high-level hubs in the southern zone of the Great Jiuzhai Ring tourist area; the northern Jiuzhaigou scenic spot had attracted many tourists due to its unique natural scenery, which had driven the development of the regional transportation system. However, it had a relatively small radiation range and further planning to promote the integrated development of transportation and tourism.

4) Social Economy Index: The three indicators that reflected the social economy index, the economic development level, the development level of tertiary industry, and the degree of industry support were not 
very spatially apparent. The values of all places in the same village were the same, so they were for reference only. The overlaid result is shown in Fig. 16 below.

Most of the zone of the Great Jiuzhai Ring tourist area is located in the mountainous area of Sichuan, and the regional economic development is relatively slow. Only Chengdu is economically developed, the related tertiary industry is well developed, and tourism support is relatively high.

\section{5) Comprehensive Evaluation of Tourism Attractiveness of the Great Jiuzhai Ring Tourist Area: Natural} condition index, tourism condition index, transportation condition index, and social economy index have a combined effect with different weights on the tourism attractiveness evaluation. The weighted overlaid result is shown in Fig. 17 below.

This evaluation system could better reflect the distribution of tourism attractiveness in the Great Jiuzhai Ring Tourist Area. Moreover, the Great Jiuzhai Ring Tourist Area was classified into five classes of unsuitable development zone (1), controlled development zone (2), medium development zone (3), suitable development zone (4), and most suitable development zone (5). Our results (Fig. 17) show that $15.78 \%$ of the study area is an unsuitable development zone, $37.74 \%$ is a controlled development zone, $27.37 \%$ medium development zone, $16.16 \%$ is a suitable development zone, and $2.95 \%$ of the study area is most suitable for tourism development. The southern regions are the most suitable regions for tourism development, while the unsuitable region's cluster is northwest. Chengdu is rich in tourist resources and has a high economic development level with a comprehensive and reasonable transportation system. Therefore, its tourism attractiveness was the highest. Hongyuan Village had fewer tourism resources with scarce transportation. Although there was an airport, the overall tourism attractiveness was weak. The Jiuzhaigou-Huanglong Scenic Area in the north relied on the attractiveness of two 5A-level scenic spots and relatively convenient transportation conditions. Although the economic development level was not high, it also had strong tourism attractiveness. Guangyuan City in the east took advantage of the favorable terrain and transportation system. Combined with its scenic spots, it also had gained high tourism attractiveness.

The distribution of tourism attractiveness of the Great Jiuzhai Ring Tourist Area can be considered to be consistent with the actual situation currently seen on the ground. The indexes in this evaluation system were all derived from various geographic information data, remote sensing data, and other objective data. The calculation results provide reliable technical support for the future development of tourism and transportation in the region.

\section{Research On The Regional Impact Of Tourism Resources Attraction}

The transportation system is an essential part of the tourism system and the primary condition for the development of tourism in a region. Right transportation conditions can enhance the attractiveness of scenic spots and increase people's willingness to travel. The transportation system and the tourism system have precise interactions: the rapid development of tourism promotes the planning and construction of the transportation system; the increasing personalized demand of tourists for scenic spots has also enhanced the tourism function of external transportation. A comprehensive and favorable 
transportation system and unique tourism transportation experience may also attract more tourists and increase the tourism attractiveness of various scenic spots.

\section{1) The Influence Analysis of Tourism Resources Attraction Distribution on the Transportation Hub: The} classification layer of tourism resources attraction was overlaid on the layer of main transportation hubs of the Great Jiuzhai Ring Tourist Area, and the result was shown in Fig. 18 below.

The first-level transportation hubs are main airports. As the most critical tourist distribution center, Chengdu could take full advantage of the first-level tourist transportation hub and is one of the most crucial transportation system nodes. As one of the most attractive scenic spots in Sichuan Province, Jiuzhaigou already has high tourism attractiveness. Coupled with Jiuhuang Airport and railway, it forms the second first-level transportation hub in the district. Mianyang City is located at the junction of highspeed, railway, national highways, and the Southern Suburb Airport, which is also the intermediate distribution point connecting Chengdu area and Guangyuan City and plays an essential role as a firstlevel tourist transportation hub.

The second-level transportation hubs are concentrated at the intersection of important highways, national highways, and provincial highways, providing tourists with the ability to move about the area freely, and is an indispensable key node for developing tourism in the region.

Chengdu has rich tourism resources, high tourism attractiveness, and a developed social economy. Correspondingly, there are more and higher-level transportation hubs. Jiuzhaigou is rich in tourism resources with high attractiveness and has higher-level hubs whose distribution is relatively sparse due to its poor social-economic conditions and sparse transit network.

\section{2) The Influence Analysis of Tourism Resources Attraction Distribution on the Transportation}

Network: The classification layer of tourism resources attraction was overlaid on the transportation system layer of the Great Jiuzhai Ring Tourist Area, and the result is shown in Fig. 19 below.

Most of the scenic spots in the Great Jiuzhai Ring Tourist Area are located near the main traffic roads, and the farther ones are also within $10 \mathrm{~km}$ of the road. At the same time, the agglomeration of scenic spots further promotes the development of the transportation system. There are a series of reasonable and comprehensive transportation systems in Qingcheng Mountain-Dujiangyan Scenic Area and Jiuzhaigou-Huanglong Scenic Area, which provides different choices for tourists with different needs, and also improves the convenience for people to tour scenic spots.

There are dense tourism resources with extremely high attractiveness in the southern region. The scenic spots' location ranges from natural scenery to historical relics, from world-class scenic spots to nationallevel scenic spots. Therefore, to connect the major scenic spots and further increase the region's tourism attractiveness, it is necessary to enhance accessibility and convenience. We continue to promote the construction of railways, highways, national highways, and provincial highways in the region in the 
future, and the rational planning of the tourism transportation systems such as tourist roads and slowmoving roads to further realize the integrated development of transportation and tourism.

There is natural scenery in the northern part of the Great Jiuzhai Ring Tourist Area. Tourists mainly go to two places, Jiuzhaigou and Huanglong, and the terrain is undulating, which is adverse for increasing the transit network's density. Therefore, the transportation mode is the central railway. The Jiuhuang Airport construction has improved the accessibility of the region, created a new distribution center, and increased its tourism attractiveness. However, the region lacks more tourism elements, and it is not appropriate to continue constructing transit networks such as national and provincial highways. There are many 4Alevel scenic spots and national-level scenic spots in the eastern region with high tourism attractiveness, located at Sichuan's junction with Shaanxi and Gansu provinces. Railways and highways crossing the area enhance the tourism attractiveness of the region. Hongyuan in the west is a patriotic tourist attraction. It is necessary to strengthen the Red Army's Long March publicity to enhance the tourism attractiveness of the place and use the Hongyuan Airport to attract more tourists.

A reasonable and comprehensive transportation system can meet tourists' travel needs, and the personalized transportation also improves people's travel experience. The planning and construction of the transportation system need to consider the overall distribution of regional tourism attractiveness, and the development of tourism resources is conversely inseparable from the confines of the transportation system. Areas with abundant tourism resources and high economic development could drive tourists' flow and promote regional transportation planning and construction. Areas with high transportation accessibility could also better promote the rapid development of the tourism industry. Even if tourism resources are attractive, the development of tourism transportation of relatively weak places is still slow. Planning should be strengthened to promote the collaborative development of tourism and transportation in this region.

\section{Conclusion}

We used AHP and Delphi method to evaluate regional tourism attractiveness and established an index system from four factors: natural condition index, tourism condition index, transportation condition index, and social economy index. The judgment matrixes were established by the expert scoring method and then solved to indicate the relative weight of each index. Next, we used GIS spatial analysis to visualize the evaluation result and formed a scientific and quantitative evaluation system to conduct our tourism attractiveness analysis.

The distribution of tourism attractiveness of the Great Jiuzhai Ring Tourist Area is generally identical with the actual situation. This evaluation system indexes are derived from various geographic information data, remote sensing data, and other objective data. The study verified the operability of the evaluation system using empirical research on the Great Jiuzhai Ring Tourist Area, thus making it possible for regional tourism transportation planning seeking to develop sustainably to use the evaluation system to choose the appropriate development direction. 
It can be seen through overlay analysis that scenic spots with high tourism attractiveness often have higher-level transportation hubs, but the distribution density of transportation hubs often depends on social-economic conditions. The transportation system and the tourism system directly influence each other, and the rapid development of the tourism industry has promoted the planning and construction of the transportation system. Based on our research, we recommended strengthening coordinated planning transportation and tourism in the region to derive layout guidance of the regional transportation network, develop unique tourism transportation products, promote the collaborative development of tourism and transportation, and further promote regional tourism to achieve integrated development of transportation and tourism. The evaluation results can provide reliable technical support for the future development of tourism and transportation in the region, scientific theoretical guidance for the further construction of hubs and networks, promote the integrated development of transportation and tourism, and finally realize regional tourism and sustainable development.

Limited by the theoretical basis and data access, the evaluation system did not consider the role of scenic spots outside the region in tourism promotion within the region, so there was a deviation at the region's edge. The selection of indexes and their weights was, to a certain extent, based on the subjective judgment of experts, possibly leading to the limitation of representation. When analyzing transportation accessibility, the radiation radii of different transportation modes were roughly divided without sufficient theoretical support. We should summarize and analyze more cases and then attempt to achieve buffer analysis of transportation hubs such as railway stations and highway exits. Future research may conduct related tourism attractiveness by applying artificial neural networks to establish a quantitative evaluation system.

\section{Declarations}

\section{Acknowledgement}

we were very grateful for the helpful comments of the anonymous reviewers. The research work was supported by the National Natural Science Foundation of China (Grant No. 51878039, No. 52078034).

\section{References}

1. Zhang, Y., Jiao, L., Yu, Z., Lin, Z. \& Gan, M. A. Tourism Route-Planning Approach Based on Comprehensive Attractiveness. IEEE Access, 8, 39536-39547 https://doi.org/10.1109/access.2020.2967060 (2020).

2. Zhou, Y., Maumbe, K., Deng, J. \& Selin, S. W. Resource-based destination competitiveness evaluation using a hybrid analytic hierarchy process (AHP): The case study of West Virginia. Tourism Management Perspectives, 15, 72-80 https://doi.org/10.1016/j.tmp.2015.03.007 (2015).

3. Boivin, M. \& Tanguay, G. A. Analysis of the determinants of urban tourism attractiveness: The case of Québec City and Bordeaux. Journal of Destination Marketing \& Management, 11, 67-79 (2019). 
4. Ristić, D., Vukoičić, D. \& Milinčić, M. Tourism and sustainable development of rural settlements in protected areas - Example NP Kopaonik (Serbia). Land Use Policy, 89, https://doi.org/10.1016/j.landusepol.2019.104231 (2019).

5. Trukhachev, A. Methodology for Evaluating the Rural Tourism Potentials: A Tool to Ensure Sustainable Development of Rural Settlements. Sustainability, 7, 3052-3070 https://doi.org/10.3390/su7033052 (2015).

6. Lv, F., Han, M. \& Qiu, T. Remote Sensing Image Classification Based on Ensemble Extreme Learning Machine With Stacked Autoencoder. IEEE Access, 5, 9021-9031 https://doi.org/10.1109/access.2017.2706363 (2017).

7. Giglio, S., Bertacchini, F., Bilotta, E. \& Pantano, P. Using social media to identify tourism attractiveness in six Italian cities. Tour. Manag, 72, 306-312 https://doi.org/10.1016/j.tourman.2018.12.007 (2019).

8. Zabihi, H. et al. A GIS-based fuzzy-analytic hierarchy process (F-AHP) for ecotourism suitability decision making: A case study of Babol in Iran. Tourism Management Perspectives, 36, https://doi.org/10.1016/j.tmp.2020.100726 (2020).

9. National Tourism Administration \& Institute of Geographic Sciences and Natural Resources \& Research, C. A. S. Classification, investigation and evaluation of tourism resources. Vol. GB/T 18972 - 201724 (General Administration of Quality Supervision, Inspection and Quarantine of the People's Republic of China (Standardization Administration of the People's Republic of China, 2017).

10. Shijin, W., Jia, X. \& Lanyue, Z. China's glacier tourism: Potential evaluation and spatial planning. Journal of Destination Marketing \& Management, 18, https://doi.org/10.1016/j.jdmm.2020.100506 (2020).

11. Tang, C., Weaver, D. \& Lawton, L. Can stopovers be induced to revisit transit hubs as stayovers? A new perspective on the relationship between air transportation and tourism. Journal of Air Transport Management, 62, 54-64 https://doi.org/10.1016/j.jairtraman.2017.02.008 (2017).

12. Albalate, D. \& Fageda, X. High speed rail and tourism: Empirical evidence from Spain. Transportation Research Part A: Policy and Practice, 85, 174-185 https://doi.org/10.1016/j.tra.2016.01.009 (2016).

13. Divisekera, S. Interdependencies of demand for international air transportation and international tourism. Tour. Econ, 22, 1191-1206 https://doi.org/10.1177/1354816616669007 (2016).

14. Rehman Khan, S. A., Qianli, D., SongBo, W., Zaman, K. \& Zhang, Y. Travel and tourism competitiveness index: The impact of air transportation, railways transportation, travel and transport services on international inbound and outbound tourism. Journal of Air Transport Management, 58, 125-134 https://doi.org/10.1016/j.jairtraman.2016.10.006 (2017).

15. Böhler, S., Grischkat, S., Haustein, S. \& Hunecke, M. Encouraging environmentally sustainable holiday travel. Transportation Research Part A: Policy and Practice, 40, 652-670 https://doi.org/10.1016/j.tra.2005.12.006 (2006).

16. Van Truong, N. \& Shimizu, T. The effect of transportation on tourism promotion: Literature review on application of the Computable General Equilibrium (CGE) Model. Transportation Research Procedia, 
25, 3096-3115 https://doi.org/10.1016/j.trpro.2017.05.336 (2017).

17. Hong Tsui, K. W. Does a low-cost carrier lead the domestic tourism demand and growth of New Zealand? Tour Manag, 60, 390-403 https://doi.org/10.1016/j.tourman.2016.10.013 (2017).

18. Gutiérrez, A., Domènech, A., Zaragozí, B. \& Miravet, D. Profiling tourists' use of public transport through smart travel card data. Journal of Transport Geography, 88, https://doi.org/10.1016/j.jtrangeo.2020.102820 (2020).

19. Deng, S., Katoh, M., Guan, Q., Yin, N. \& Li, M. Interpretation of Forest Resources at the Individual Tree Level at Purple Mountain, Nanjing City, China, Using WorldView-2 Imagery by Combining GPS, RS and GIS Technologies. Remote Sensing, 6, 87-110 https://doi.org/10.3390/rs6010087 (2013).

20. Noguera, J. M., Barranco, M. J., Segura, R. J. \& Martínez, L. A mobile 3D-GIS hybrid recommender system for tourism. Inf. Sci, 215, 37-52 https://doi.org/10.1016/j.ins.2012.05.010 (2012).

21. Özceylan, E., Çetinkaya, C., Erbaş, M. \& Kabak, M. Logistic performance evaluation of provinces in Turkey: A GIS-based multi-criteria decision analysis. Transportation Research Part A: Policy and Practice, 94, 323-337 https://doi.org/10.1016/j.tra.2016.09.020 (2016).

22. Mishra, A. K., Deep, S. \& Choudhary, A. Identification of suitable sites for organic farming using AHP \& GIS. The Egyptian Journal of Remote Sensing and Space Science, 18, 181-193 https://doi.org/10.1016/j.ejrs.2015.06.005 (2015).

23. Allafta, H., Opp, C. \& Patra, S. Identification of Groundwater Potential Zones Using Remote Sensing and GIS Techniques: A Case Study of the Shatt Al-Arab Basin. Remote Sensing, 13, https://doi.org/10.3390/rs13010112 (2020).

24. Yu, Y. C. \& Wang, W. Application of GIS and Artificial Neural Network Model Ecotourism Relevancy Evaluation. Applied Mechanics and Materials, 556-562, 5776-5779 https://doi.org/10.4028/www.scientific.net/AMM.556-562.5776 (2014).

25. Bi, J. W., Liu, Y. \& Li, H. Daily tourism volume forecasting for tourist attractions. Annals of Tourism Research, 83, https://doi.org/10.1016/j.annals.2020.102923 (2020).

26. González-Ramiro, A., Gonçalves, G., Sánchez-Ríos, A. \& Jeong, J. Using a VGI and GIS-Based Multicriteria Approach for Assessing the Potential of Rural Tourism in Extremadura (Spain). Sustainability, 8, https://doi.org/10.3390/su8111144 (2016).

27. Cheng, Q., Su, B. \& Tan, J. Developing an evaluation index system for low-carbon tourist attractions in China- A case study examining the Xixi wetland. Tour. Manag, 36, 314-320 https://doi.org/10.1016/j.tourman.2012.10.019 (2013).

28. Trukhachev, A. Methodology for Evaluating the Rural Tourism Potentials: A Tool to Ensure Sustainable Development of Rural Settlements. Sustainability, 7, 3052-3070 https://doi.org/10.3390/su7033052 (2015).

29. Bunruamkaew, K. \& Murayam, Y. Site Suitability Evaluation for Ecotourism Using GIS \& AHP: A Case Study of Surat Thani Province, Thailand. Procedia - Social and Behavioral Sciences, 21, 269-278 https://doi.org/10.1016/j.sbspro.2011.07.024 (2011). 
30. Kanwal, S., Rasheed, M. I., Pitafi, A. H., Pitafi, A. \& Ren, M. Road and transport infrastructure development and community support for tourism: The role of perceived benefits, and community satisfaction. Tour. Manag, 77, https://doi.org/10.1016/j.tourman.2019.104014 (2020).

31. Walsh, J. J. et al. Acute aerobic exercise impairs aspects of cognitive function at high altitude. Physiol Behav, 223, 112979 https://doi.org/10.1016/j.physbeh.2020.112979 (2020).

32. Liu, Y. et al. Effect of hypoxia on human cognitive ability and indoor oxygen environment demand for sojourners at high altitude. Building and Environment, 194, https://doi.org/10.1016/j.buildenv.2021.107678 (2021).

33. Ministry of Water Resources of the People's Republic of China. Comprehensive Control of Soil and Water Conservation-General Rule of Planning. Vol.GB/T 15772 - 200848 (General Administration of Quality Supervision (Inspection and Quarantine of the People's Republic of China;Standardization Administration of the People's Republic of China, 2017).

34. Saaty, T., Group decision making and the AHP. In The Analytic Hierarchy Process; Golden, B.L., Wasil, E.A., Harker, P.T., Eds.;Springer: Berlin/Heidelberg, Germany, 1980.

35. Saaty, T. The Analytic Hierarchy Process 12th edn (McGraw-Hill International Book Co., New York, NY, USA, 1980).

36. Xiao, Z. et al. Tourism Route Decision Support Based on Neural Net Buffer Analysis. Procedia Computer Science, 107, 243-247 https://doi.org/10.1016/j.procs.2017.03.086 (2017).

37. Kolcsár, R. A., Csikós, N. \& Szilassi, P. Testing the limitations of buffer zones and Urban atlas population data in urban green space provision analyses through the case study of Szeged. Hungary. Urban Forestry \& Urban Greening, 57, https://doi.org/10.1016/j.ufug.2020.126942 (2021).

38. Neuvonen, M., Pouta, E., Puustinen, J. \& Sievänen, T. Visits to national parks: Effects of park characteristics and spatial demand. Journal for Nature Conservation, 18, 224-229 https://doi.org/10.1016/j.jnc.2009.10.003 (2010).

39. Shao, Z., Huq, M. E., Cai, B., Altan, O. \& Li, Y. Integrated remote sensing and GIS approach using Fuzzy-AHP to delineate and identify groundwater potential zones in semi-arid Shanxi Province, China. Environ. Model. Softw, 134, https://doi.org/10.1016/j.envsoft.2020.104868 (2020).

40. Ministry of Culture and Tourism of the People's Republic of China. Tourism Sample Survey Data: Beijing, China, 2018.

\section{Figures}




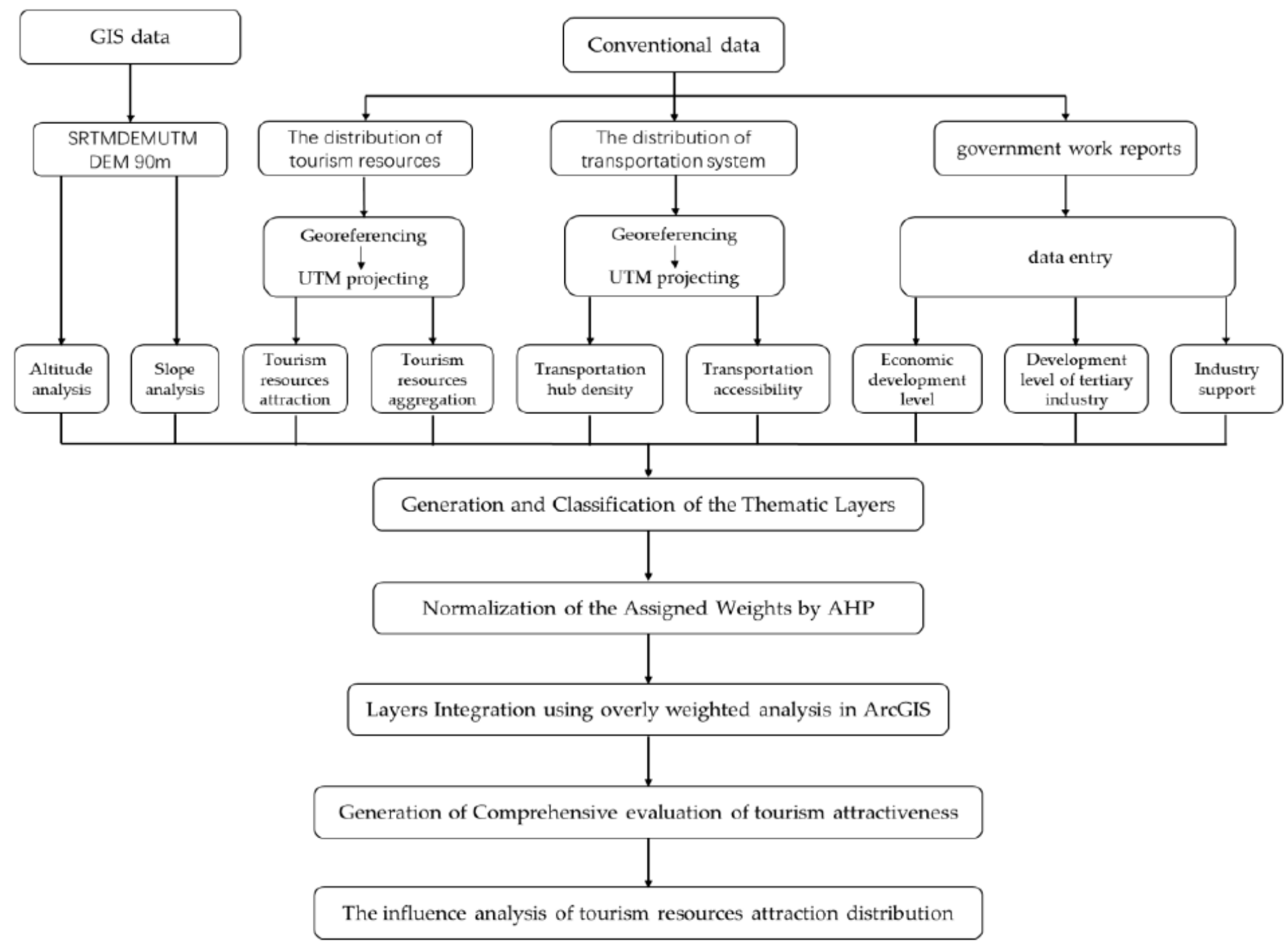

Figure 1

Altitude classification layer 


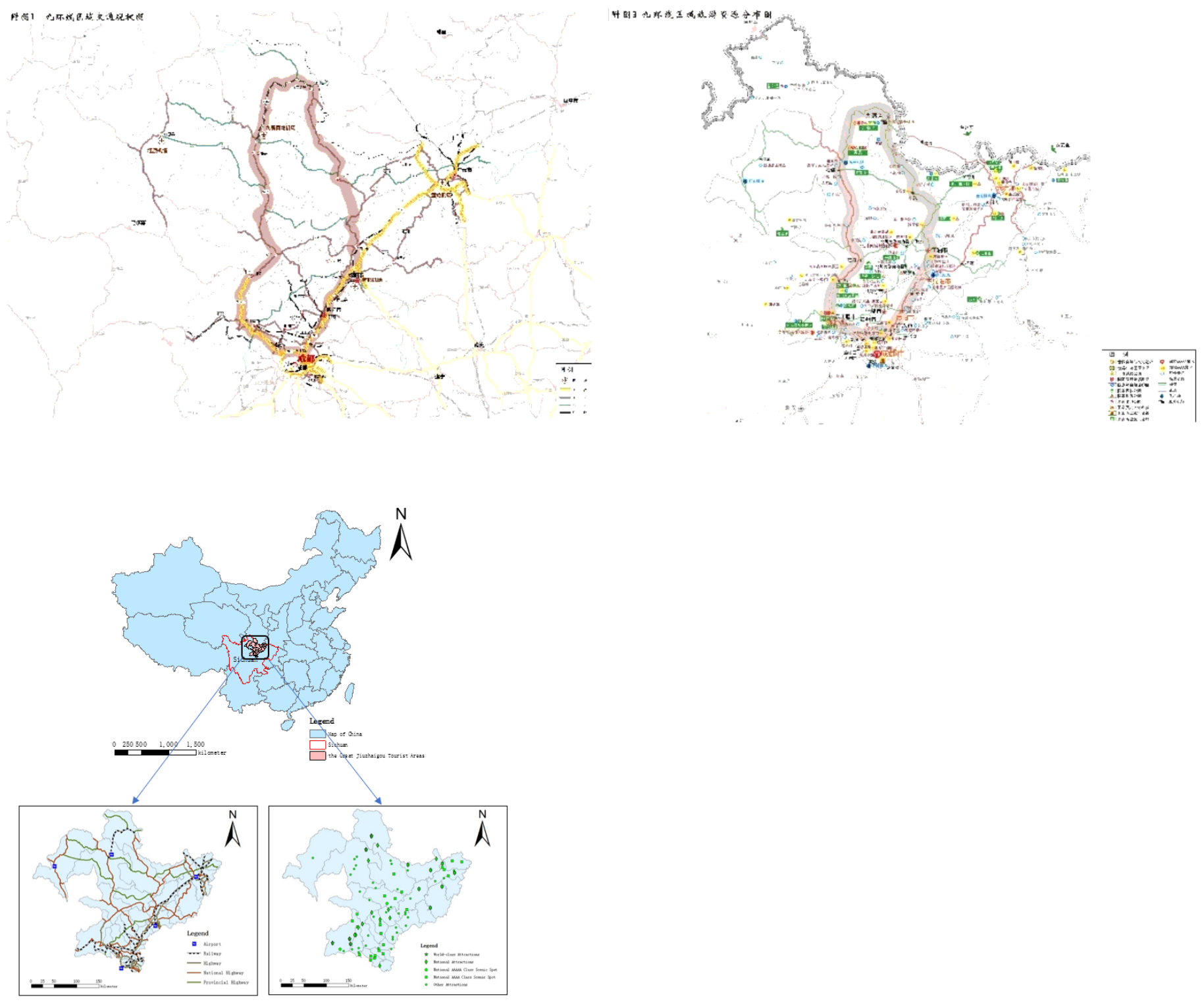

Figure 2

Distribution of transportation system and tourism resources in the Great Jiuzhai Ring Tourist Area. (a) distribution maps of the transportation system and scenic spots; (b) distribution vectors of the transportation system and scenic spots 


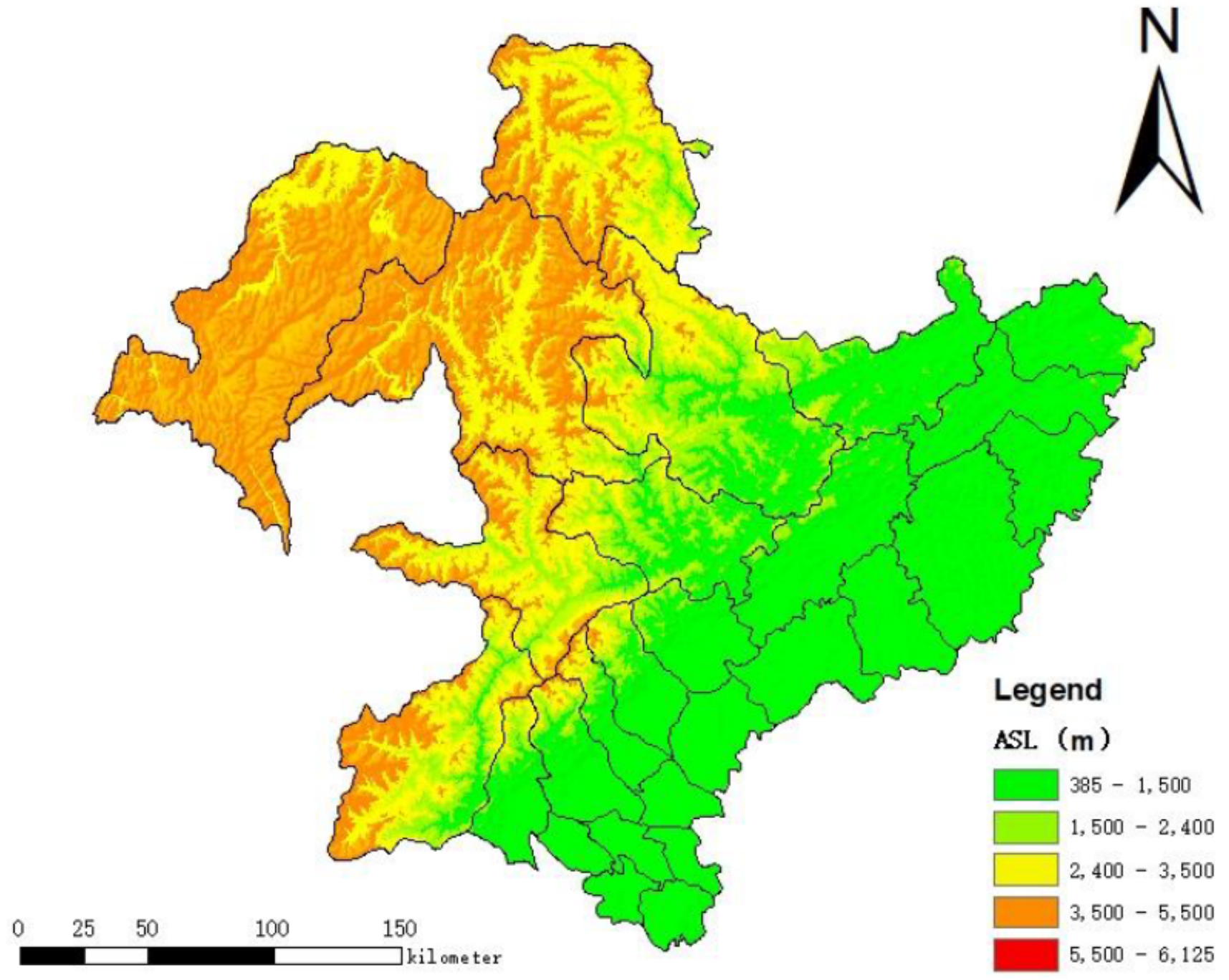

Figure 3

Altitude classification layer 


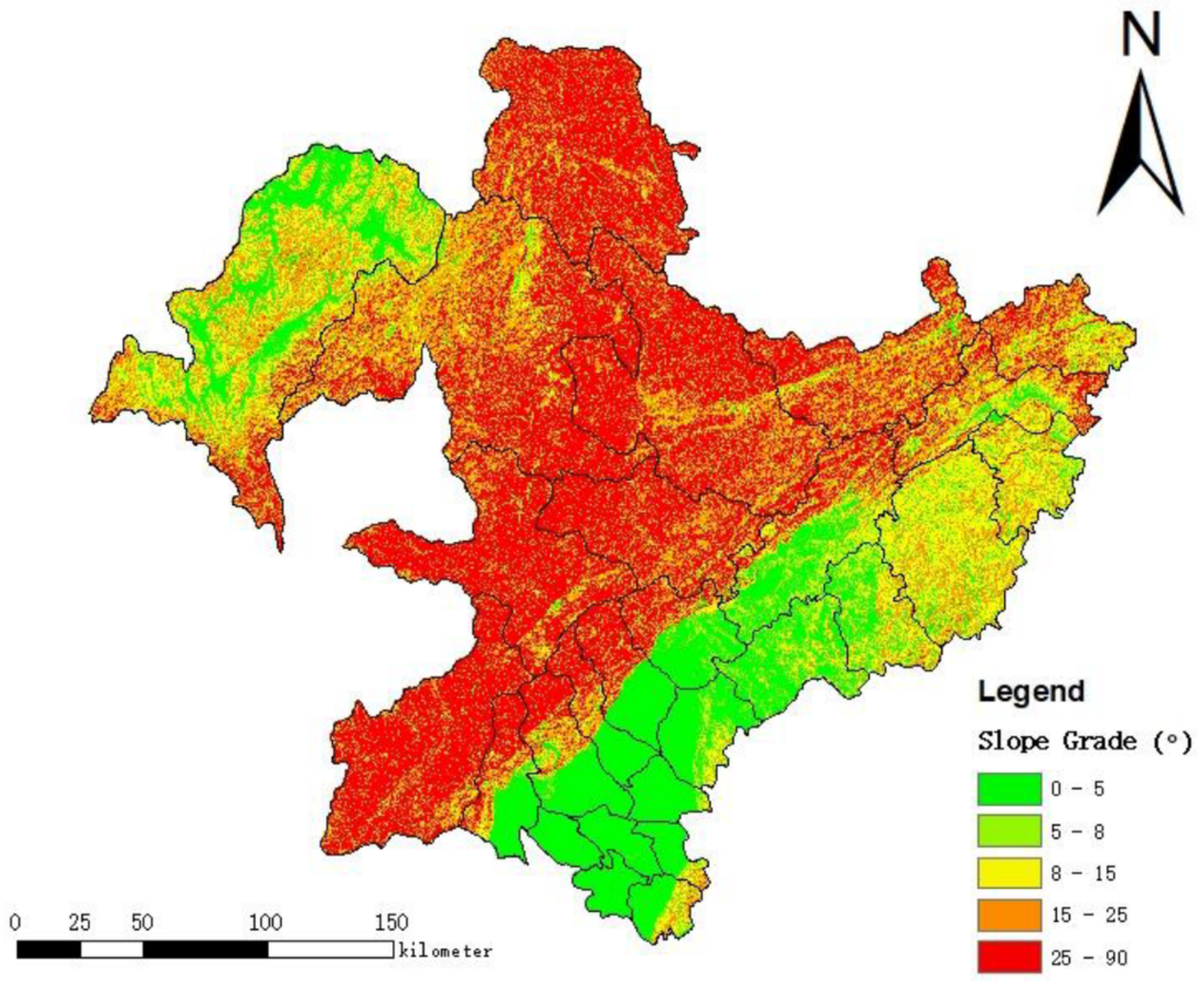

Figure 4

Slope classification layer 


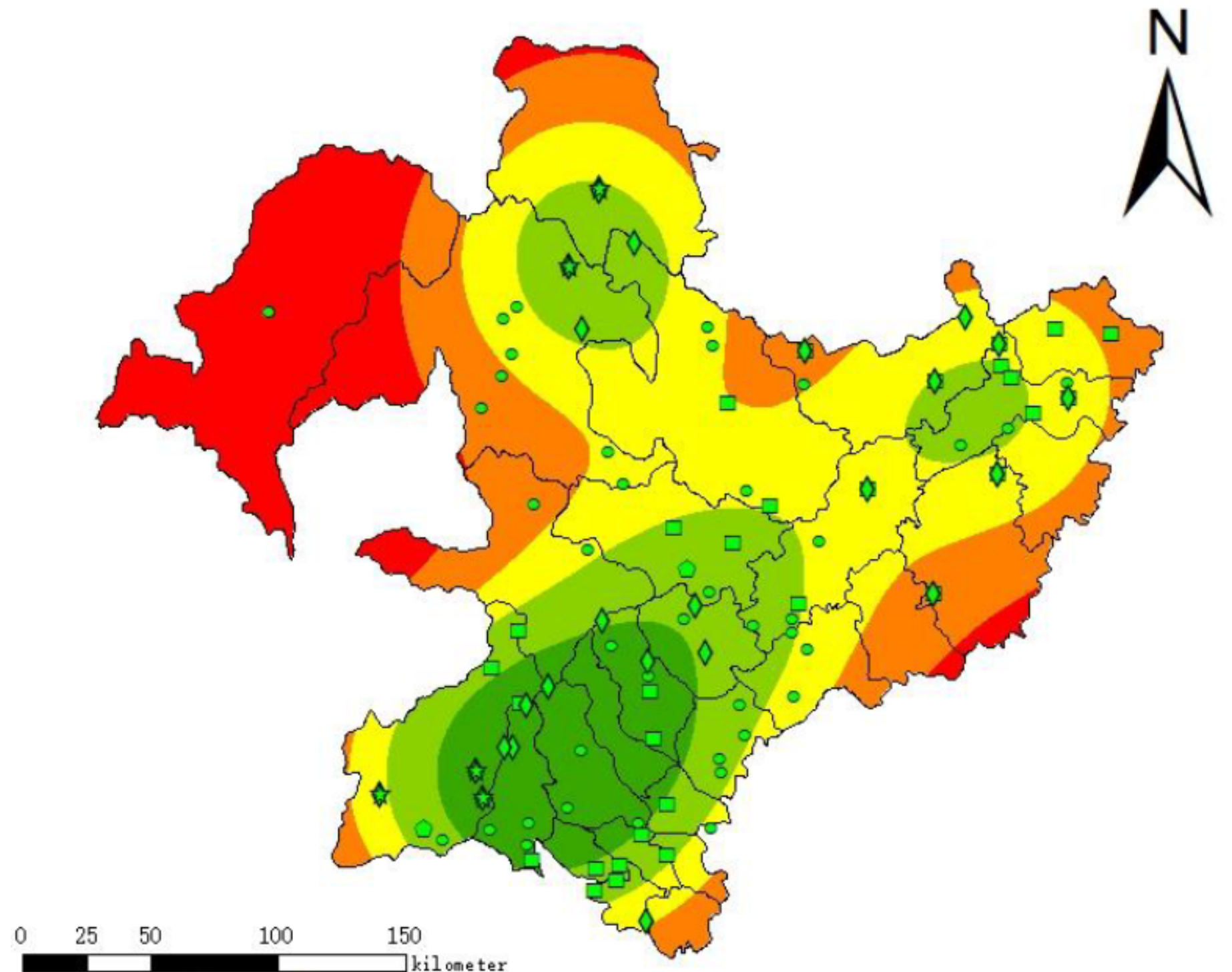

Legend

World-class Attractions

Tourism Resources Attraction

$\diamond$ National Attractions

- National AARA Class Scenic Spot

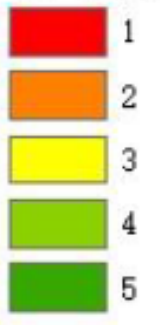

Figure 5

Classification layer of tourism resources attraction 


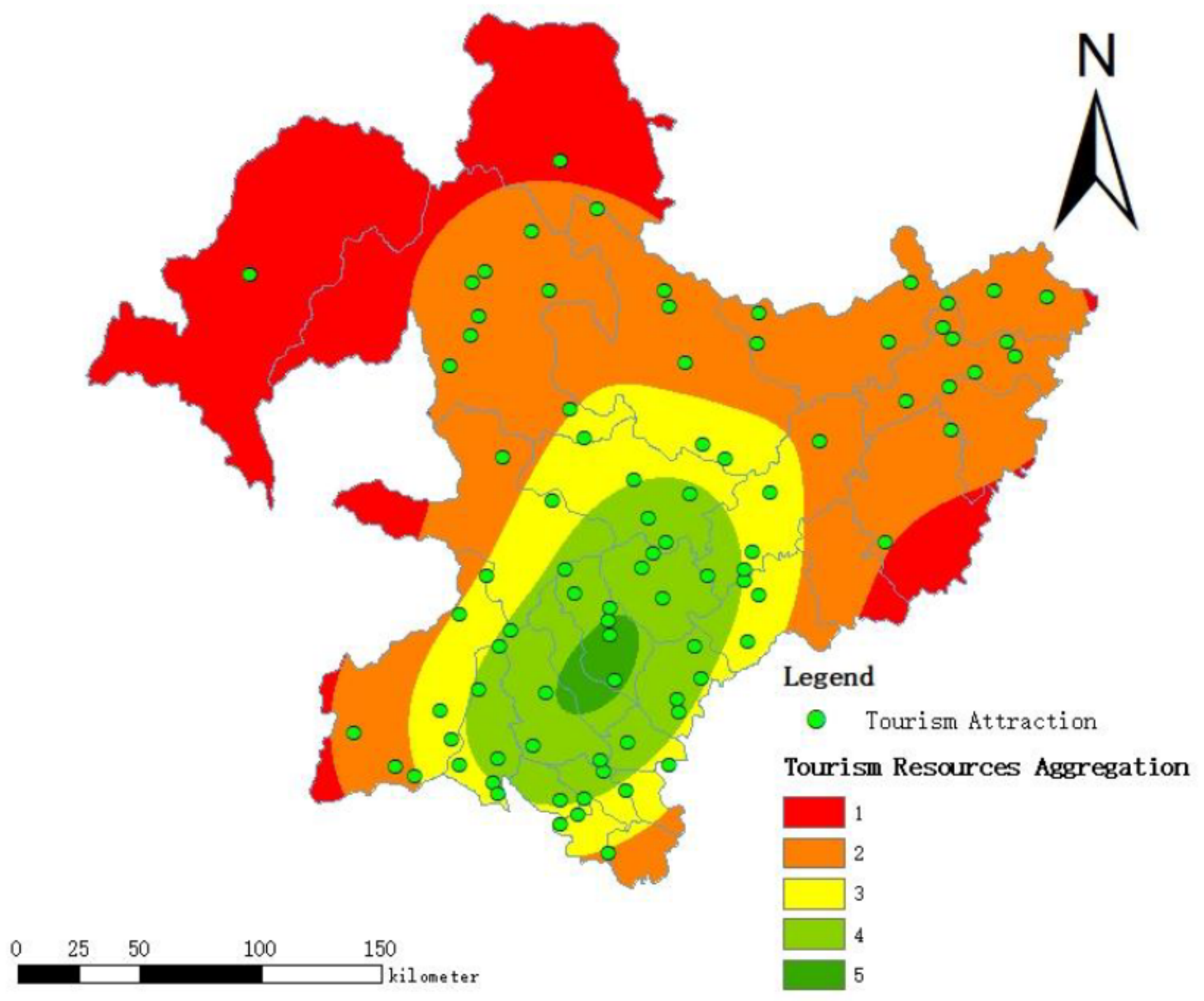

Figure 6

Classification layer of tourism resource agglomeration 


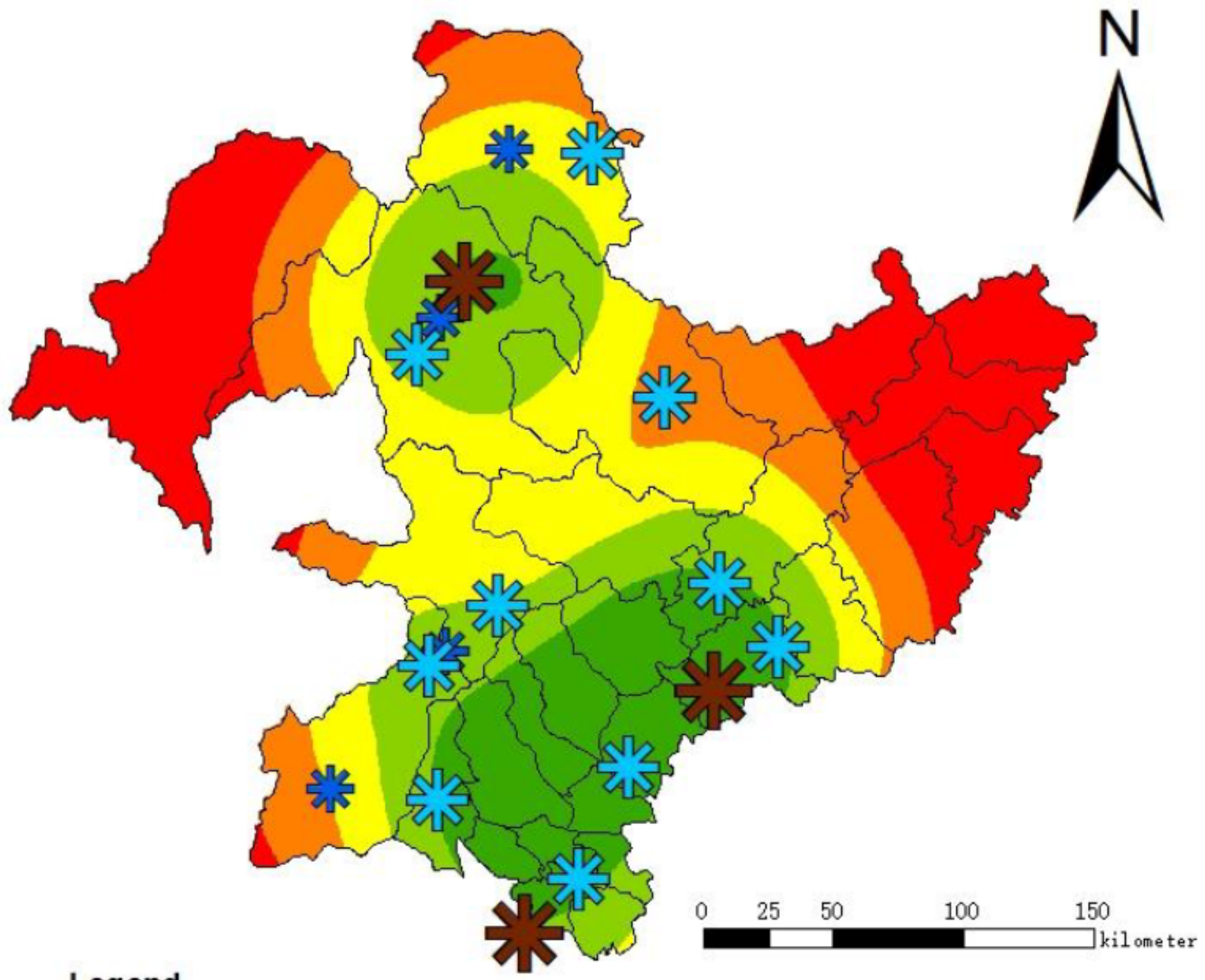

\section{Legend}

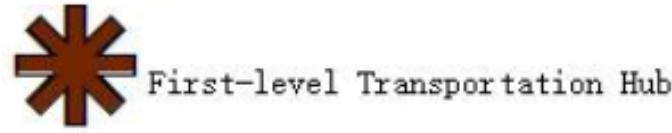

Second-level Transportation Hub

The Third-level Transportation Hub
Hub Density

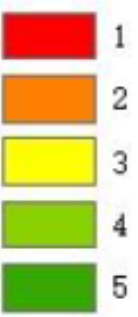

Figure 7

Classification layer of transportation hubs density 


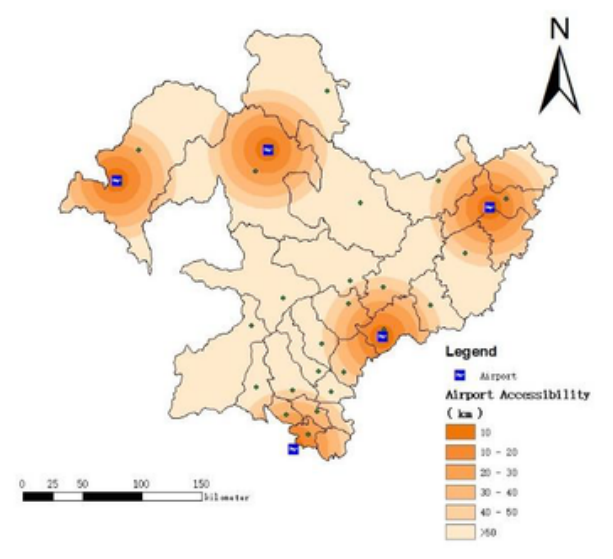

(a)

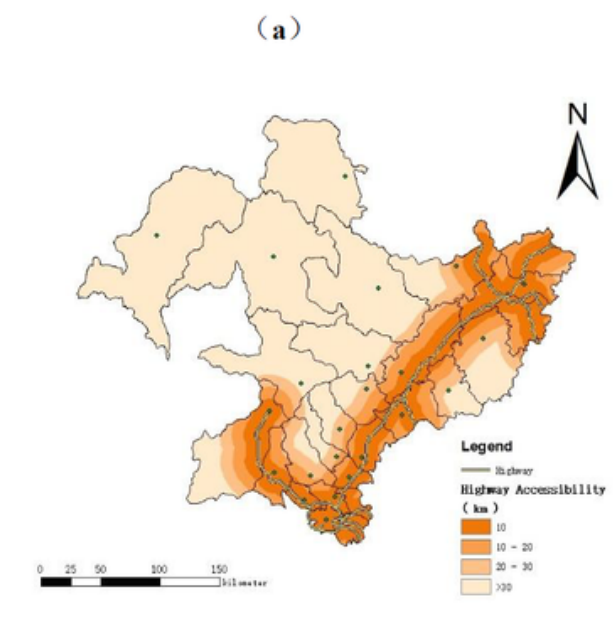

(c)

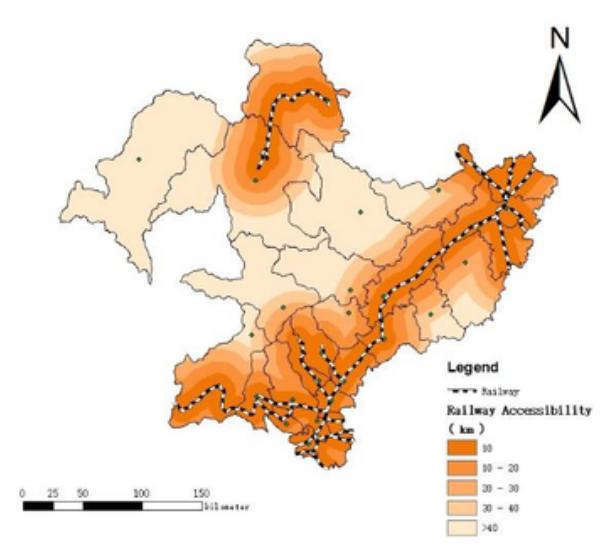

(b)

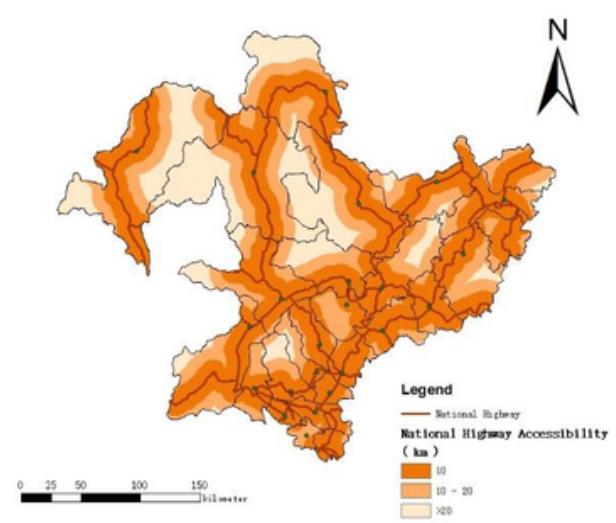

(d)

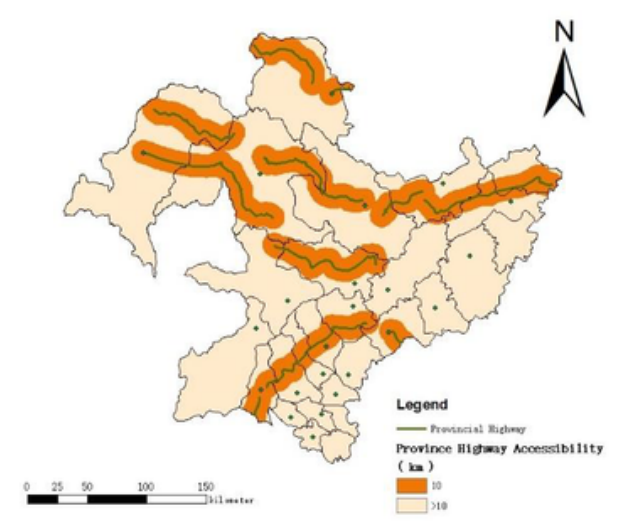

(e)

\section{Figure 8}

Accessibility of various transportation. (a)Airports accessibility; (b)Railways accessibility; (c)Highways accessibility (d)National highways accessibility; (e)Provincial highways accessibility 


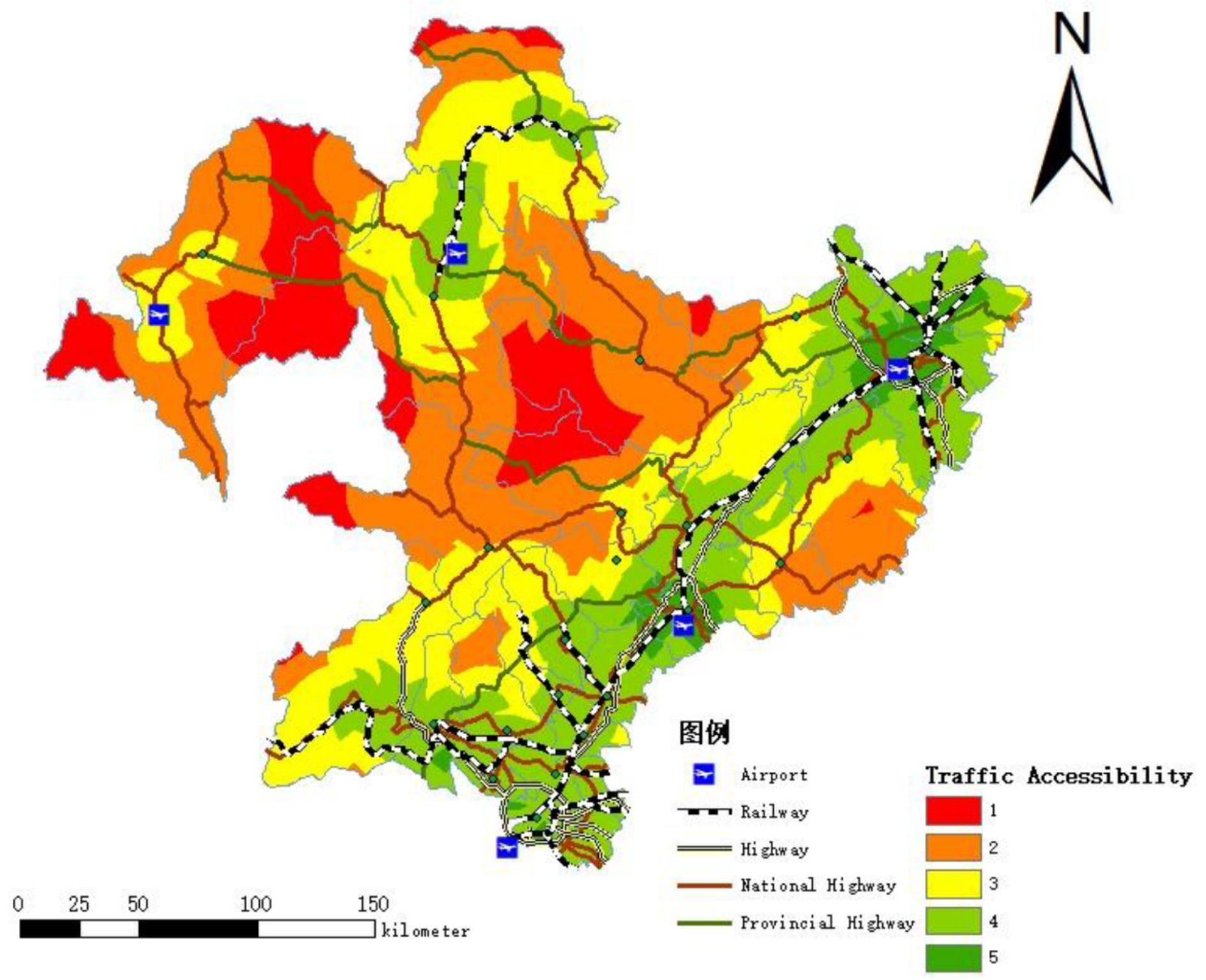

Figure 9

Classification layer of transportation accessibility 


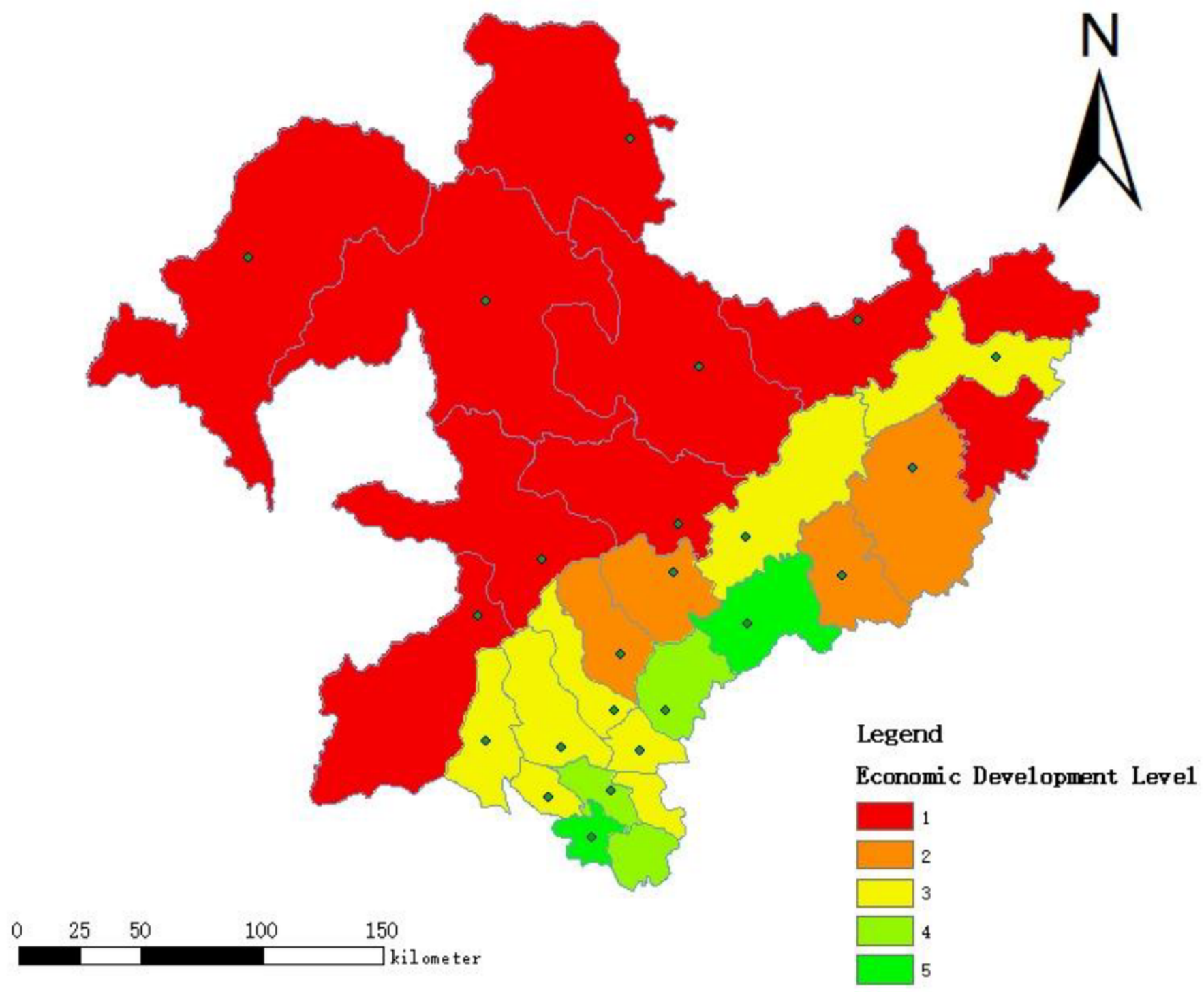

Figure 10

Classification layer of economic development level 


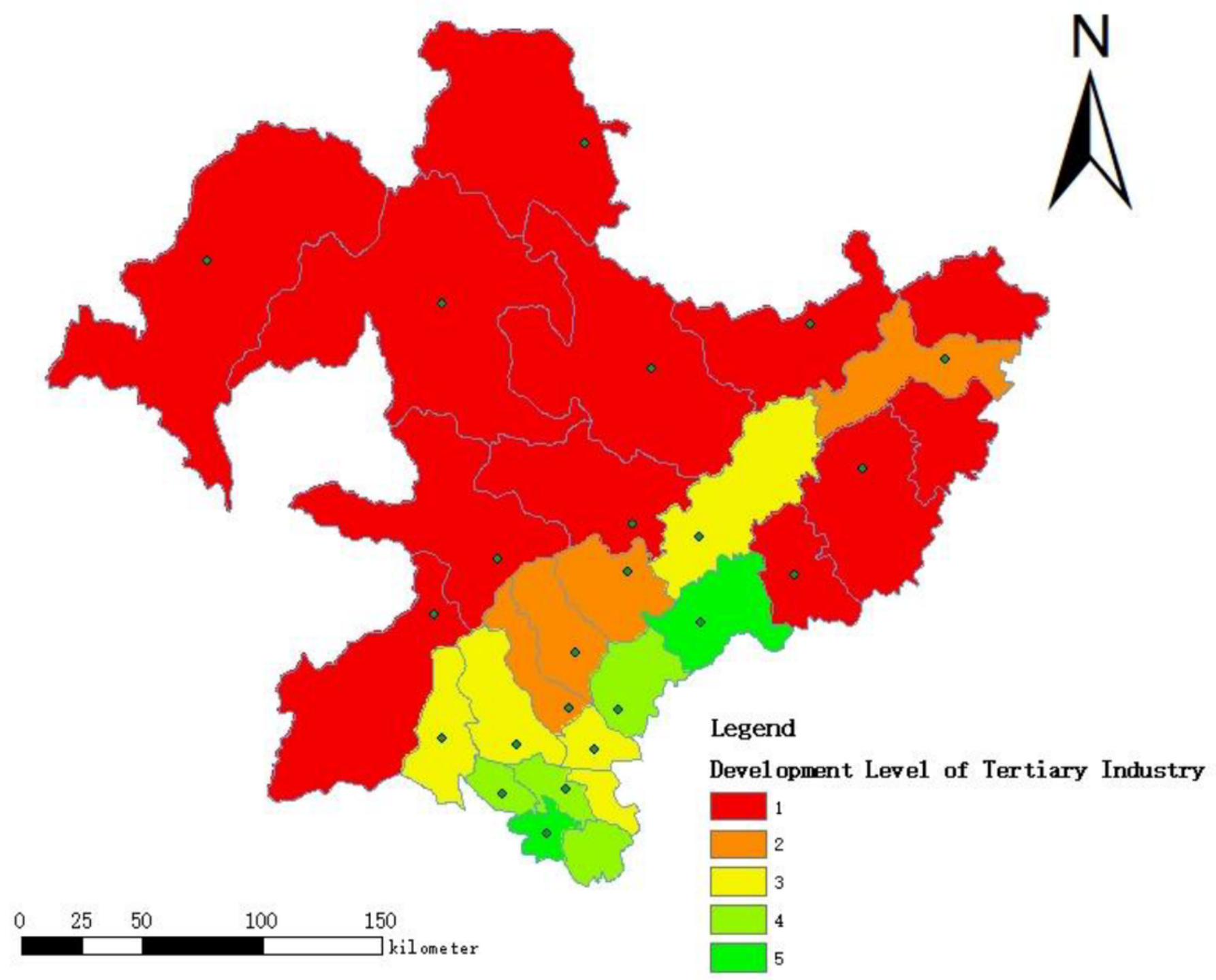

Figure 11

Classification layer of development level of tertiary industry 


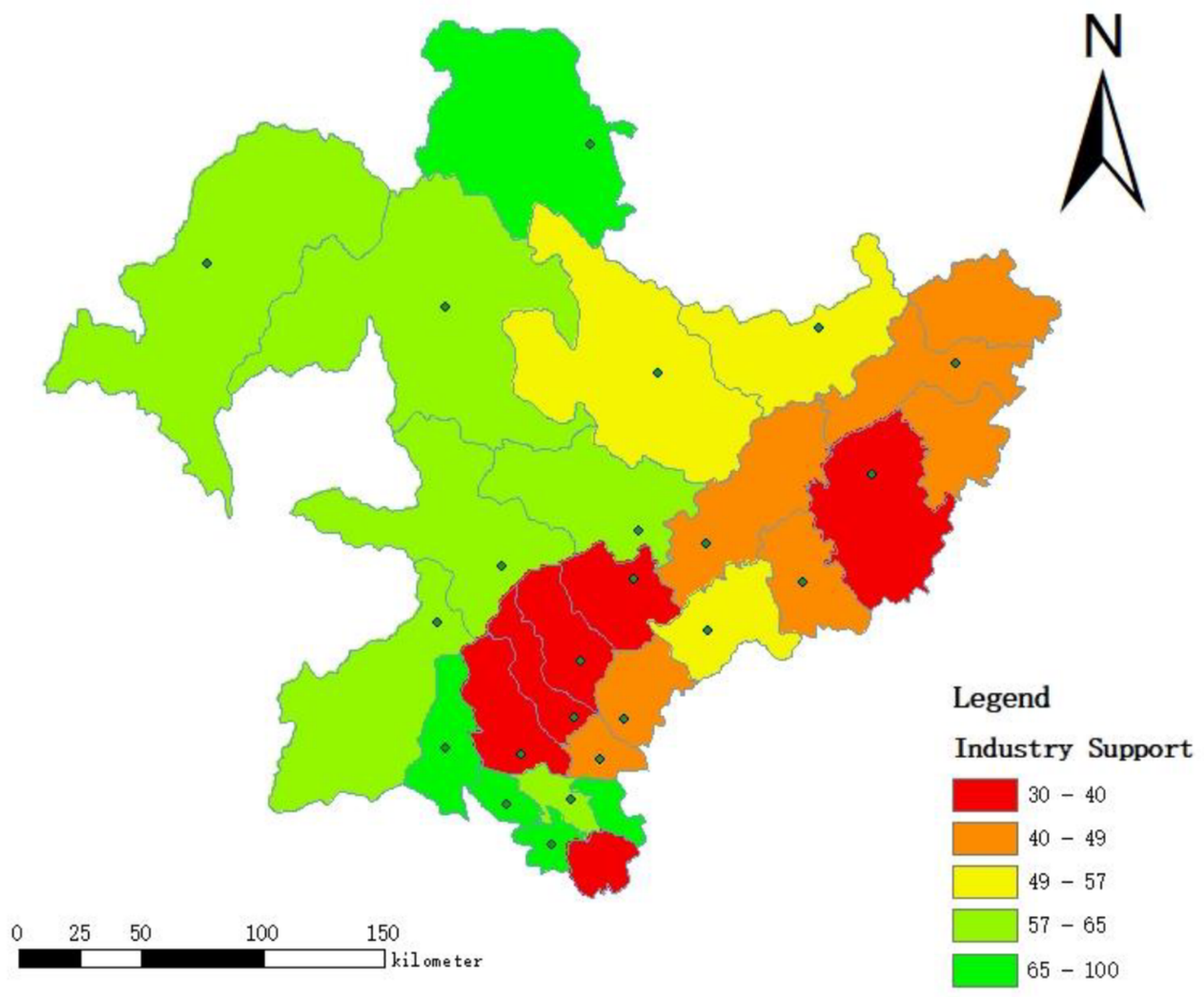

Figure 12

Classification vector of industry support 


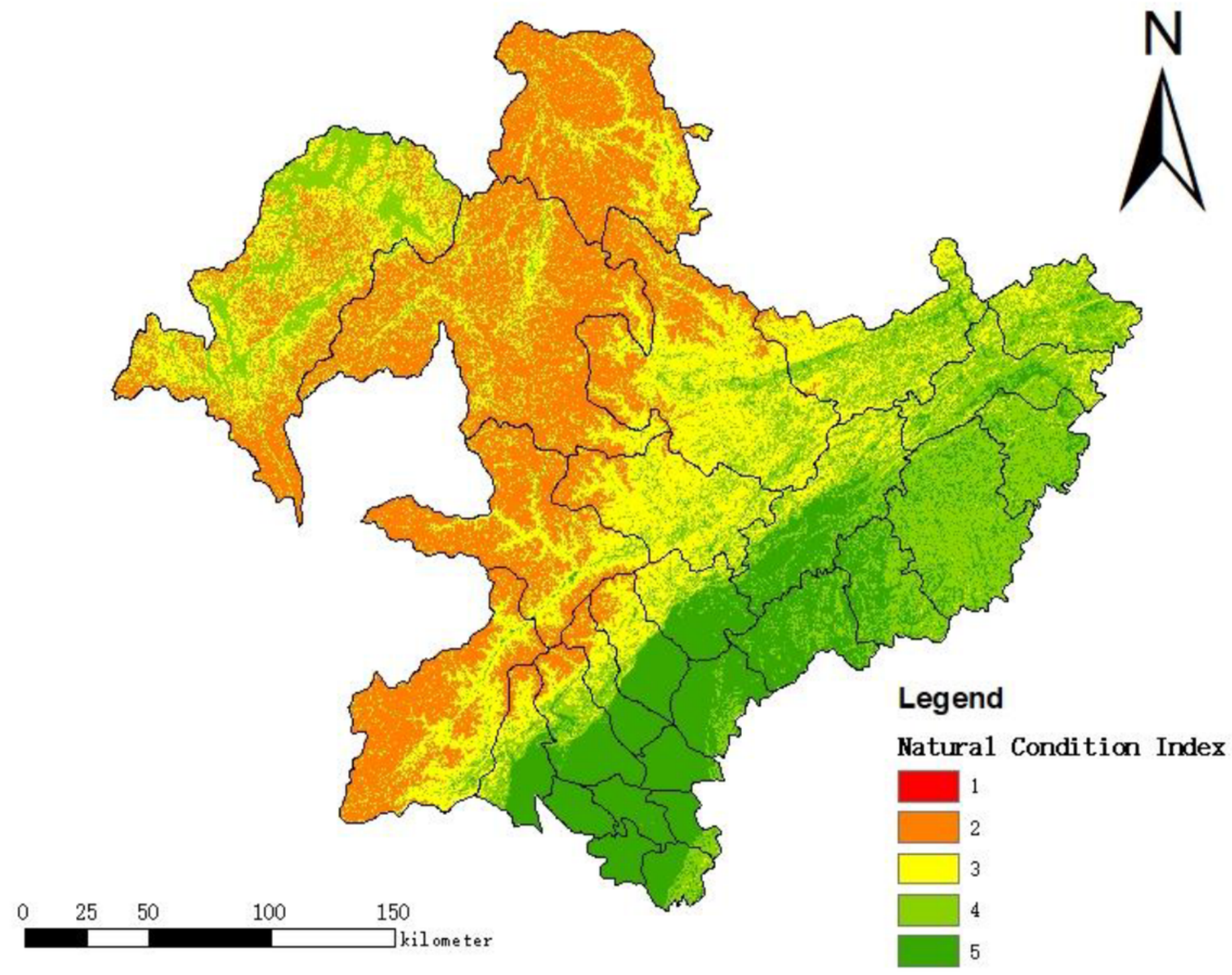

Figure 13

Classification layer of natural condition index 


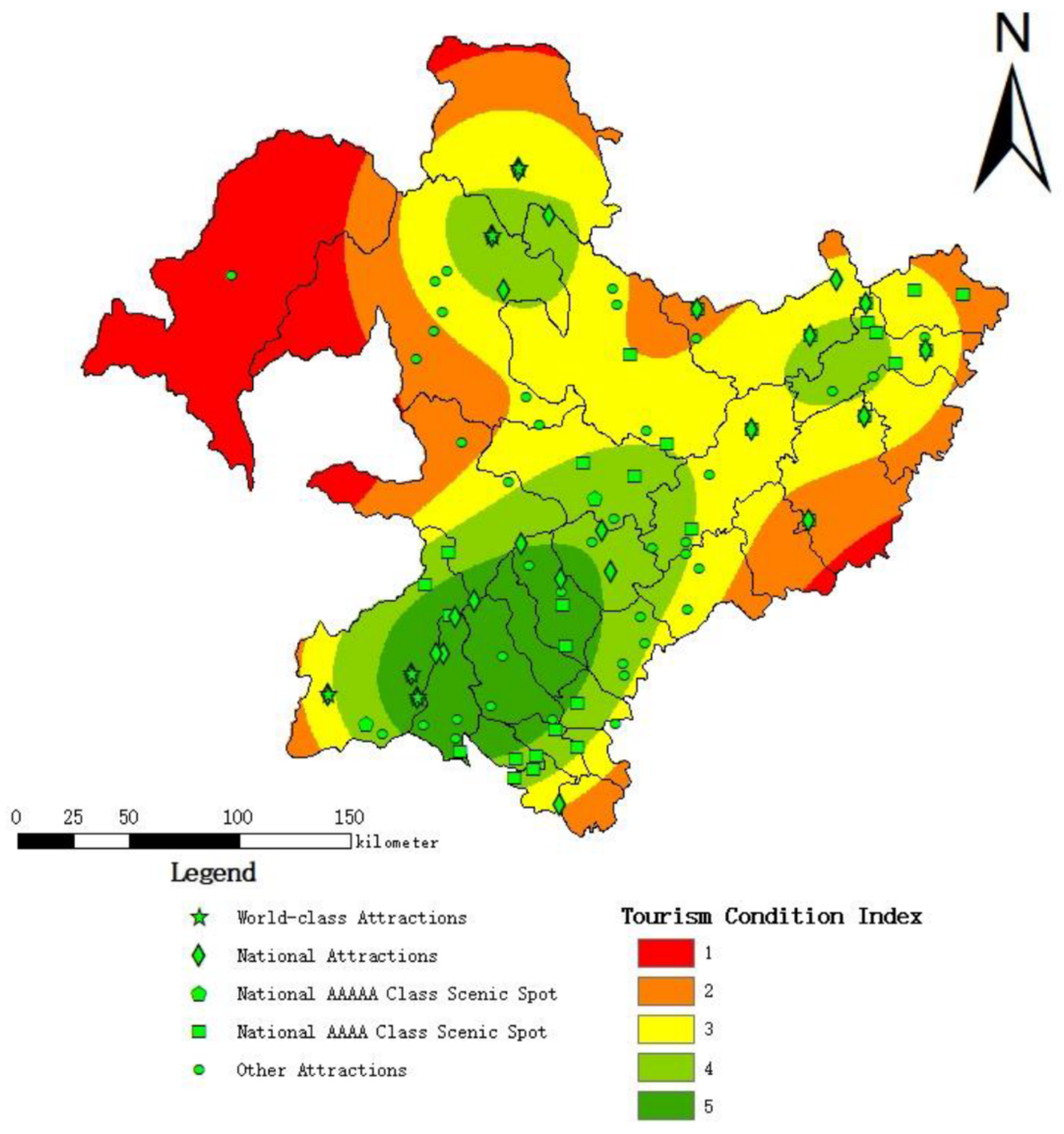

Figure 14

Classification layer of tourism condition index 


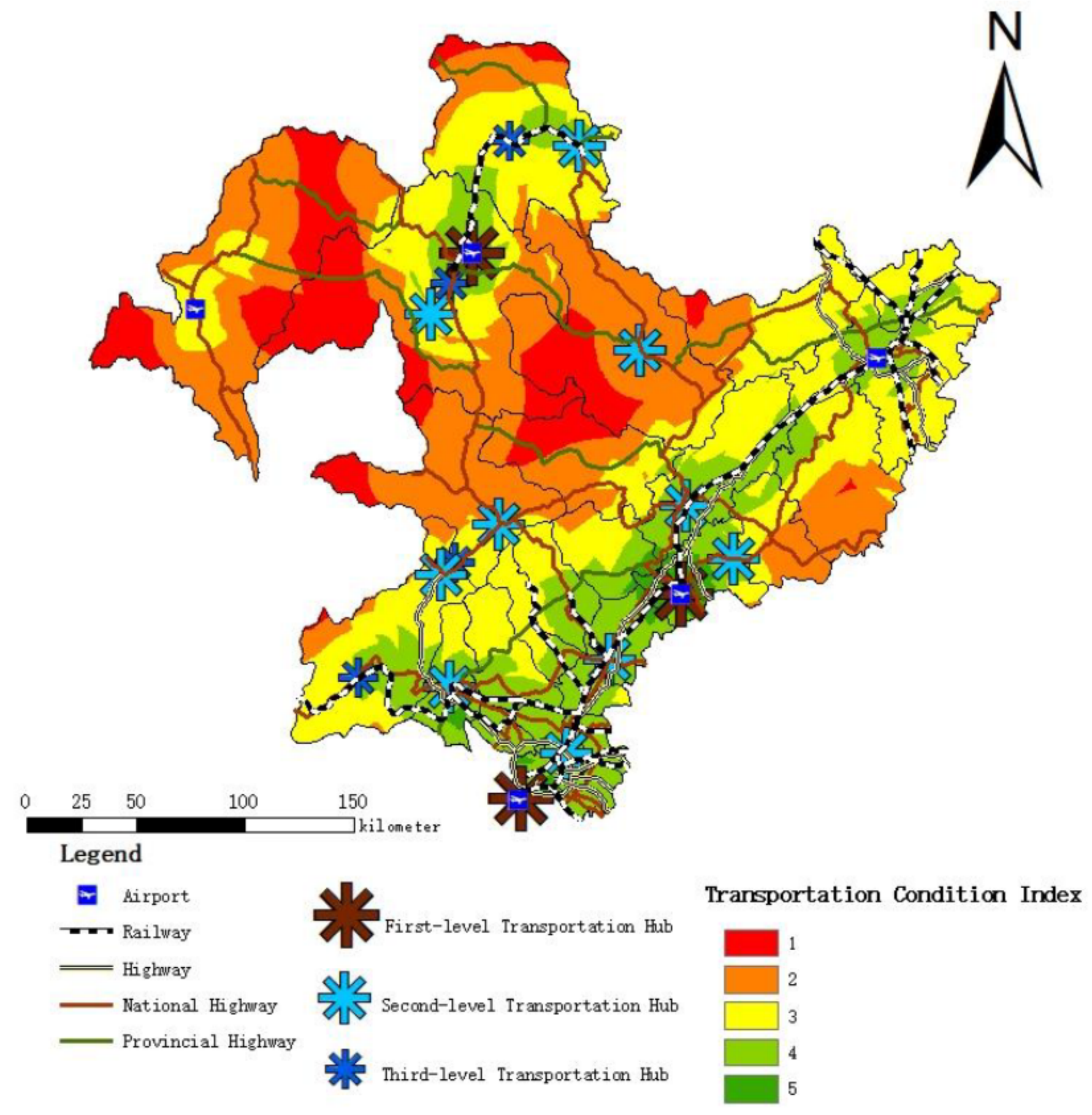

Figure 15

Classification layer of transportation index 


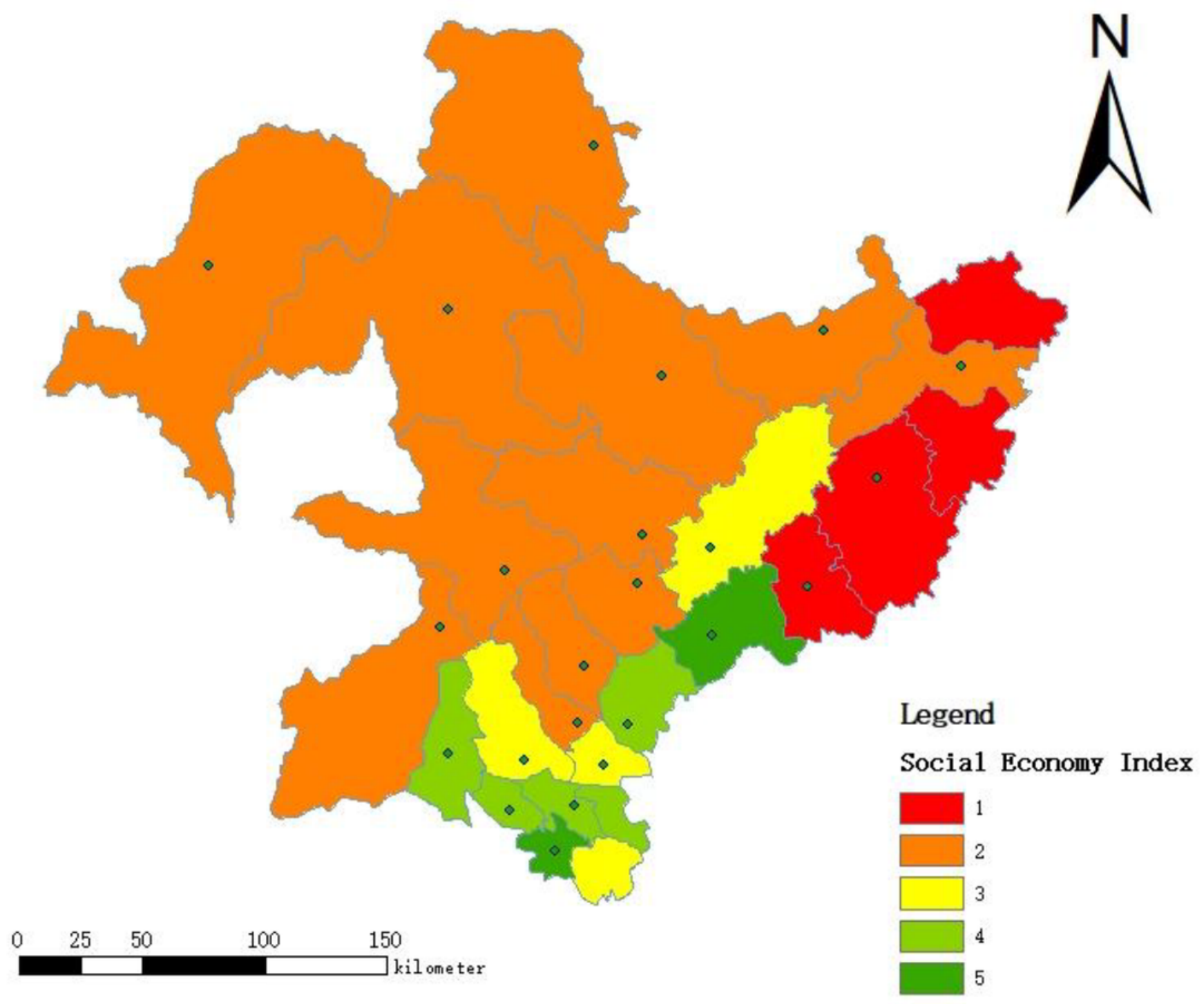

Figure 16

Classification layer of social economy index 


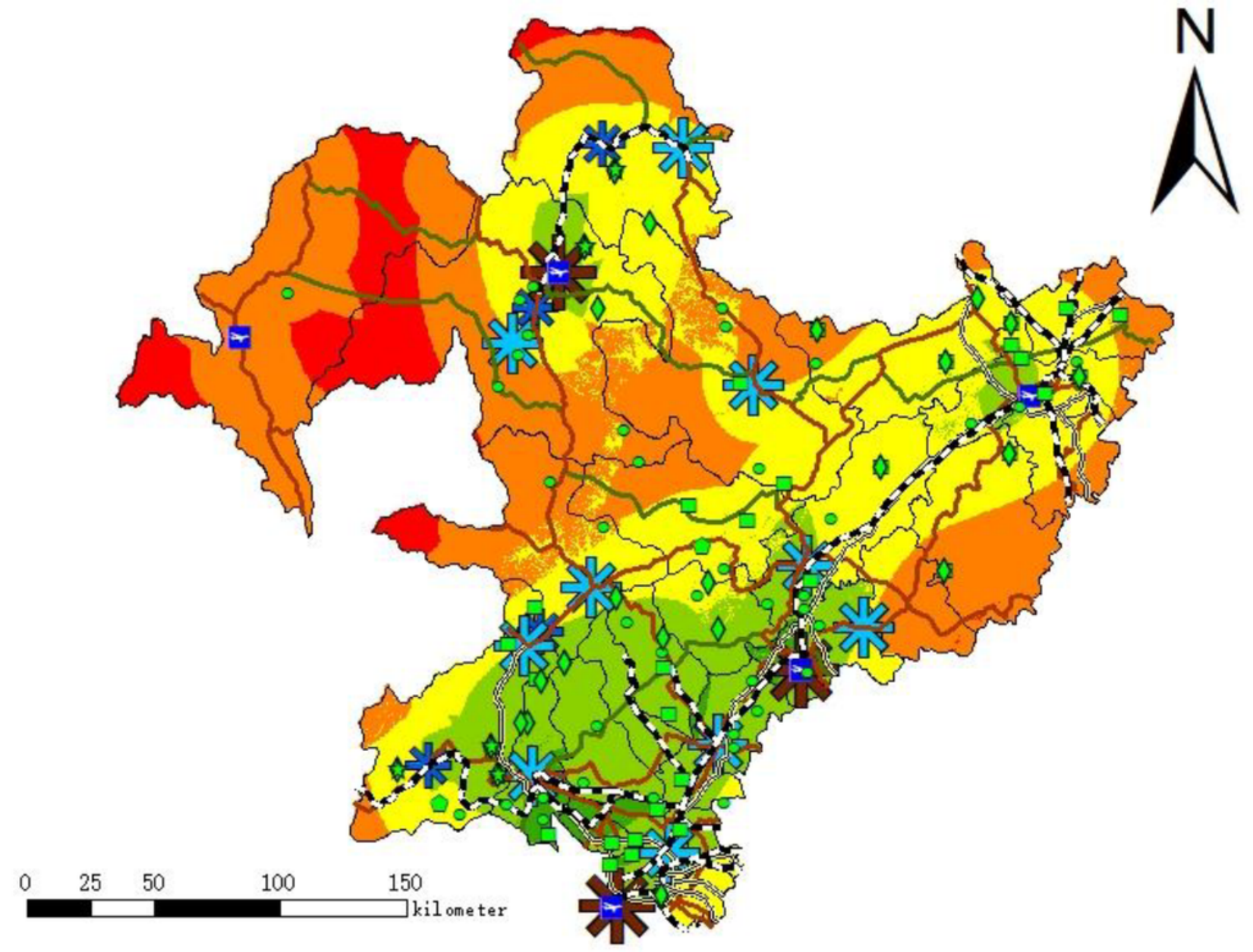

\section{Legend}

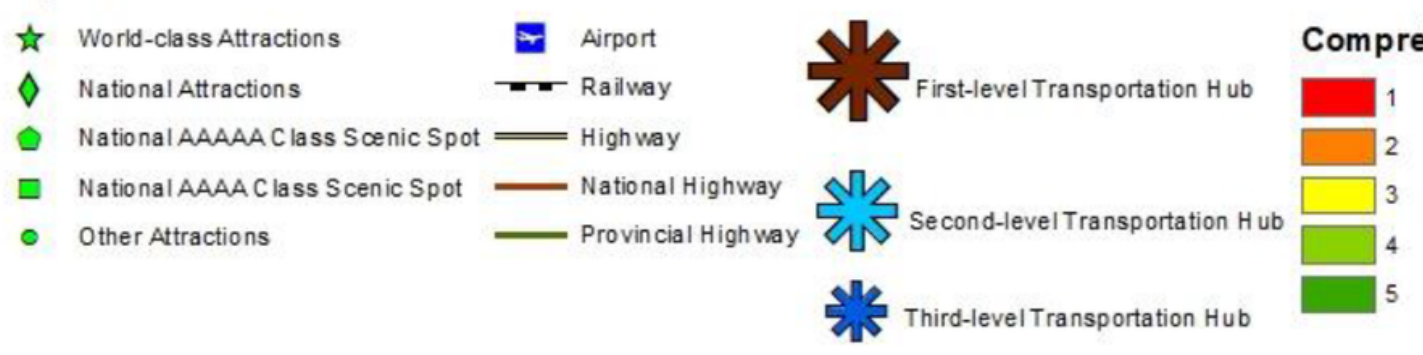

Figure 17

The comprehensive evaluation of tourism attractiveness of the Great Jiuzhai Ring Tourist Area 


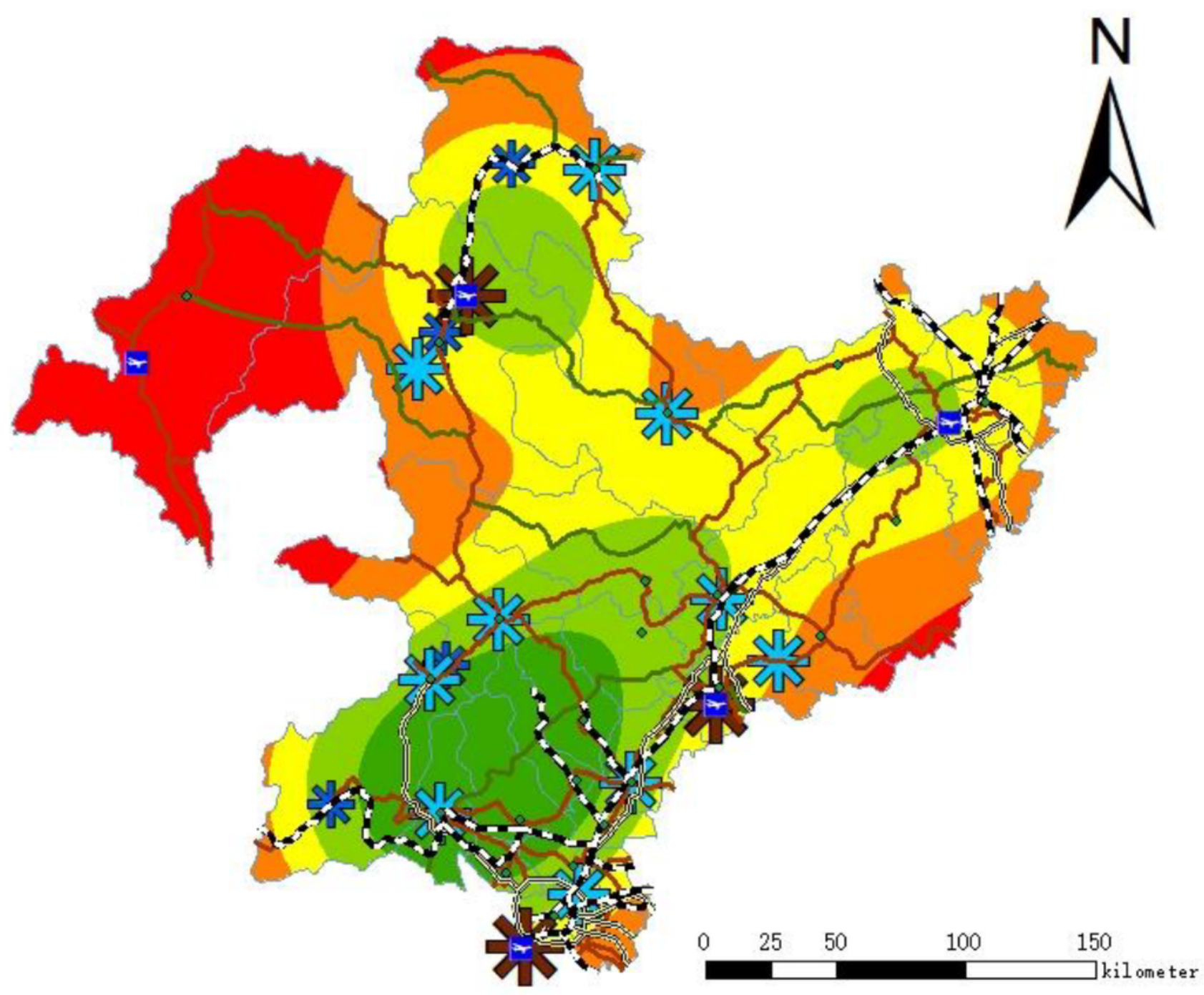

\section{Legend}

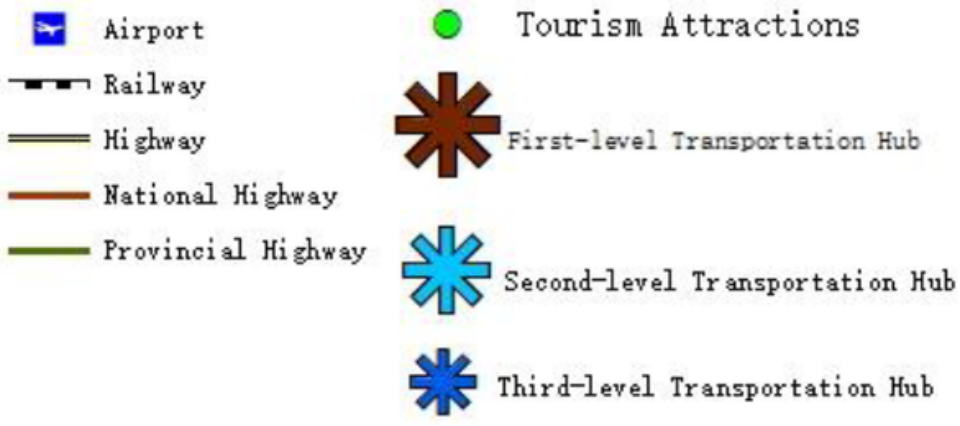

Tourisn Attraction

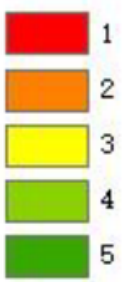

Figure 18

Overlaid layers of transportation hubs and tourism resources attraction 


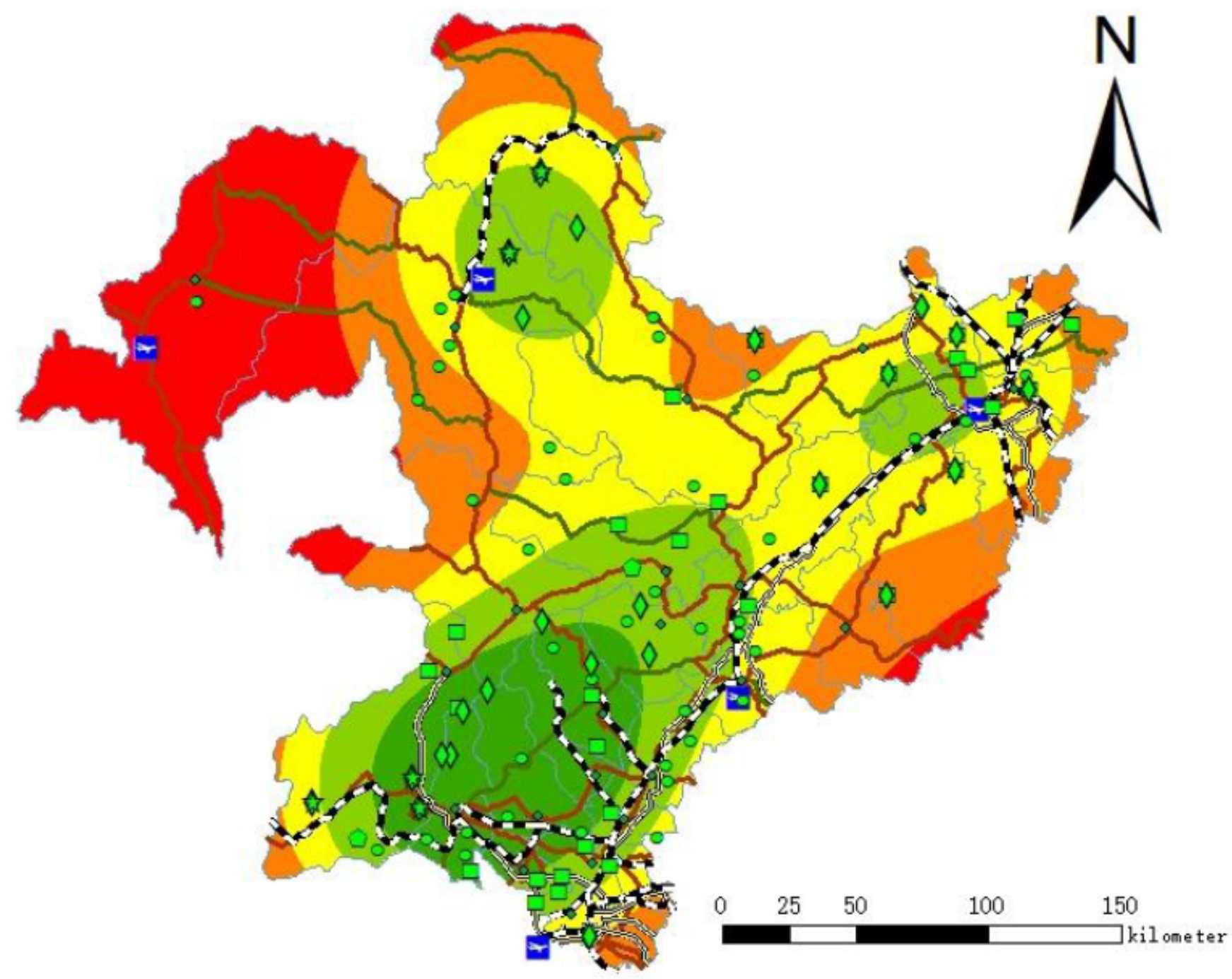

\section{Legend}

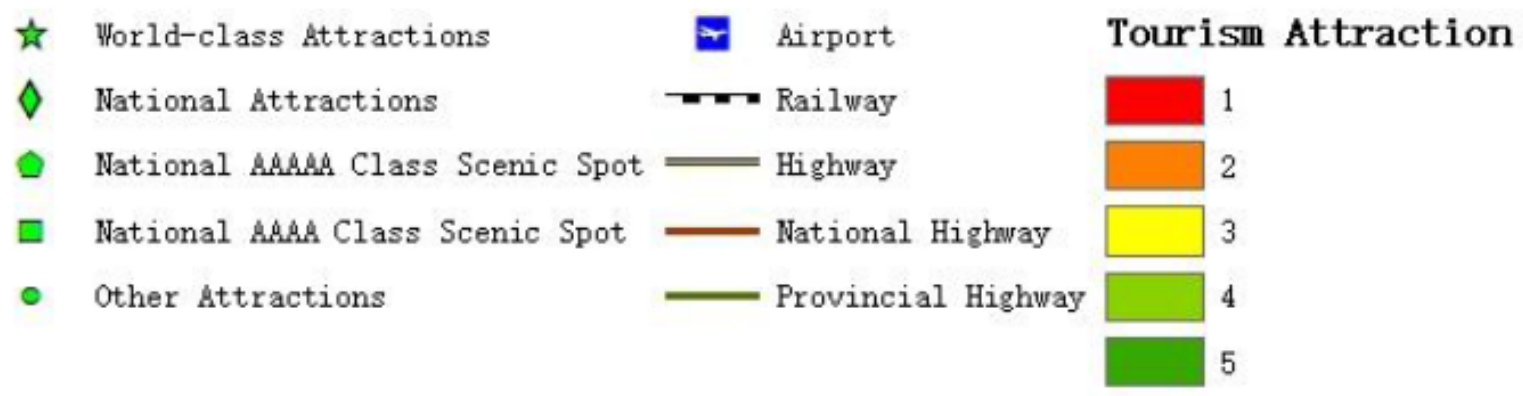

Figure 19

The Overlaid layer of the transportation system and tourism resources attraction 